\title{
Crystal and electronic structures of $\mathrm{Ni}(\mathrm{II})$ silanethiolates
}

\section{containing flexible diamine ligands}

Agnieszka Pladzyk $^{\mathrm{a}^{*}}$, Andrzej Ozarowski $^{\mathrm{b}}$, Łukasz Ponikiewski $^{\mathrm{a}}$

${ }^{a}$ Gdańsk University of Technology, Department of Inorganic Chemistry, Narutowicza St. 11/12 80-233, Gdańsk, Poland

${ }^{\mathrm{b}}$ National High Magnetic Field Laboratory, Florida State University, 1800 E. Paul Dirac Dr., Tallahassee, Florida 32310-3706 United States

* Corresponding author. e-mail address: agnieszka.pladzyk@pg.gda.pl (A. Pladzyk), tel.: +48 583472329; fax.: +48 583472694. 
Abstract: Five nickel(II) complexes containing aliphatic diamines and tri-tertbutoxysilanethiolate ligand have been synthesized for the purpose of studying their structural, spectral (IR, UV-Vis, HF EPR) and thermal properties. Complexes (1)-(5) have been prepared in high yield by reactions of $\left[\mathrm{Ni}\left\{\mathrm{SSi}(\mathrm{O} t \mathrm{Bu})_{3}\right\}_{2}\left(\mathrm{NH}_{3}\right)\left(\mathrm{H}_{2} \mathrm{O}\right)\right]$ with 1.3-propanediamine $\left(\mathbf{L}_{\mathbf{1}}\right)$, 1,6-hexanediamine $\left(\mathbf{L}_{\mathbf{2}}\right)$, or 1,7-heptanediamine $\left(\mathbf{L}_{\mathbf{3}}\right)$. The X-ray structures were determined for complexes $\quad\left[\mathrm{Ni}\left\{\left(\mathrm{SSi}(\mathrm{O} t \mathrm{Bu})_{3}\right\}_{2}\left(\mathrm{~L}_{1}\right)_{2}\right] \quad(\mathbf{1}), \quad\left[\mathrm{Ni}\left\{\left(\mathrm{SSi}(\mathrm{O} t \mathrm{Bu})_{3}\right\}_{2}\left(\mu-\mathrm{L}_{2}\right)_{2}\right]_{n} \quad\right.\right.$ (2) and $\left[\mathrm{Ni}\left\{\left(\mathrm{SSi}(\mathrm{O} t \mathrm{Bu})_{3}\right\}_{2}\left(\mu-\mathrm{L}_{3}\right)_{4}\right]_{n}\right.$ (3). Compound (1) is mononuclear with $\mathrm{Ni}(\mathrm{II})$ ions coordinated by two molecules of chelating 1.3-diaminepropane. Complexes (2) and (3) consist of 1D polymeric structures with $\mathrm{Ni}(\mathrm{II})$ atoms bridged by diamine molecules. The coordinated atoms and the nickel atom form a $\mathrm{NiN}_{2} \mathrm{~S}_{2}$ square-planar core in polymeric (2) and a distorted transoctahedral $\mathrm{NiN}_{4} \mathrm{~S}_{2}$ core in mononuclear (1) and polynuclear (3). Reactions of $\left[\mathrm{Ni}\left\{\mathrm{SSi}(\mathrm{O} t \mathrm{Bu})_{3}\right\}_{2}\left(\mathrm{NH}_{3}\right)\left(\mathrm{H}_{2} \mathrm{O}\right)\right]$ with 1,4-butanediamine $\left(\mathbf{L}_{\mathbf{4}}\right)$ and 1,5-pentanediamine $\left(\mathbf{L}_{\mathbf{5}}\right)$ resulted in single crystals of compounds (4) and (5) which were not suitable for X-ray measurements. The spin Hamiltonian parameters $g, D$, and $E$ were determined for compound (1) from high-field HF EPR spectra.

Keywords: Nickel(II); Tri-tert-butoxysilanethiol; Crystal structure; FT-IR; HF EPR; Thermal analysis.

\section{Introduction}

Coordination chemistry of paramagnetic nickel is still the centre of interest of many scientists. In the majority of studies on the nickel thiolate complexes, they were used as model compounds for elucidating the structure and function of active sites of nickel enzymes [1-8]. They have also been reported as potential precursors of NiS nanoparticles which have been found to be highly active catalysts for hydrodesulfurization and autothermal reforming of methane for hydrogen production [9-11]. Quite recently, many studies have been dedicated to the identification of magnetostructural properties of polynuclear nickel(II) complexes [12-14]. So far, no HFEPR measurements on octahedral Ni(II) thiolates have been reported [15-20]. Therefore we decided to synthesize heteroleptic Ni(II) complexes with $\mathrm{S}$ - and $\mathrm{N}$-donor ligands and characterize their molecular and electronic structures.

Generally, investigations of transition metal thiolates are not simple. This is caused by the tendency of thiolate ligands to bridge metal centers yielding practically insoluble polymers and by their air sensitivity which may lead to the oxidative coupling formation of sulfides 
[21]. For these reasons we used $(t \mathrm{BuO})_{3} \mathrm{SiSH}$ as a thiol derivative. In spite of the bulky size, this compound adopts various coordination modes and acts as a S-monodentate, S,O-bidentate and S-bridging ligand in reactions with transition metals [22,23]. It also turned out to be a good cysteine analog in syntheses of biomimetic systems [24] and finally and perhaps most importantly, this compound appeared to be relatively stable during syntheses performed in the presence of air [25]. So far, we have obtained mono- and polynuclear nickel(II) compounds by a simple reaction between $\mathrm{Ni}(\mathrm{II})$ ions, $\mathrm{R}_{3} \mathrm{SiSH}$ and monodentate $\mathrm{N}$-donor ligands [26-28]. In this paper we present the X-ray structures and analysis of IR, UV-vis spectra of a new mononuclear complex $\left[\mathrm{Ni}\left\{\left(\mathrm{SSi}(\mathrm{O} t \mathrm{Bu})_{3}\right\}_{2}\left(\mathrm{C}_{3} \mathrm{H}_{10} \mathrm{~N}_{2}\right)_{2}\right](\mathbf{1})\right.$, as well as of two polynuclear species $\left[\mathrm{Ni}\left\{\left(\mathrm{SSi}(\mathrm{O} t \mathrm{Bu})_{3}\right\}_{2}\left(\mu-\mathrm{C}_{6} \mathrm{H}_{16} \mathrm{~N}_{2}\right)_{2}\right]_{\mathrm{n}} \quad\right.$ (2) and $\left[\mathrm{Ni}\left\{\left(\mathrm{SSi}(\mathrm{O} t \mathrm{Bu})_{3}\right\}_{2}\left(\mu-\mathrm{C}_{7} \mathrm{H}_{18} \mathrm{~N}_{2}\right)_{4}\right]_{\mathrm{n}} \quad\right.$ (3), which contain flexible aliphatic diamines as $\mathrm{N}$-donor ligands (Scheme 1). Compounds (1) and (3) exhibit strongly distorted octahedral geometry on $\mathrm{Ni}$ (II) ions and have been examined with the use of HFEPR.

\section{Experimental}

\subsection{Physical measurements}

The elemental analyses (C, H, S and N contents) were performed on an Elemental Analyser EA 1108 (Carlo Erba Instruments). The IR spectra were measured for crystalline compounds in the range of 4000 to $400 \mathrm{~cm} \_1$ with a Nicolet iS50 FTIR spectrometer equipped with the Specac Quest single-reflection diamond attenuated total reflectance (ATR) accessory. Spectral analysis was controlled by the OMNIC software package. Electronic spectra were recorded with an Evolution 220UV-Vis Thermo Scientific spectrometer (solid state). Thermogravimetric analysis was performed under argon using a Netzsch thermobalance TG 209 coupled with a Bruker IFS66 FTIR spectrometer. The volatiles evolving from the heated sample were transported to the spectrometer chamber in the stream of argon via a thermostated pipe. EPR spectra at temperatures ranging from ca. $5 \mathrm{~K}$ to $30 \mathrm{~K}$ were recorded on a home-built spectrometer at the EMR facility of the NHMFL [29]. The microwaves were generated by a phase-locked Virginia Diodes source generating frequency of $13 \pm 1 \mathrm{GHz}$ and producing its harmonics up to ca. $650 \mathrm{GHz}$. A superconducting magnet (Oxford Instruments) capable of reaching a field of $17 \mathrm{~T}$ was employed.

\subsection{Synthesis of complexes (1)-(5)}


Tri-tert-butoxysilanethiol was synthesized as reported previously [25]. The synthesis of $\left[\mathrm{Ni}\left\{\mathrm{SSi}(\mathrm{O} t \mathrm{Bu})_{3}\right\}_{2}\left(\mathrm{NH}_{3}\right)\left(\mathrm{H}_{2} \mathrm{O}\right)\right]$ is described in Supplementary Materials. All other materials were obtained from commercial sources without further purification. Complexes (1)-(5) were obtained according to the same synthetic procedure: to a solution of $\left[\mathrm{Ni}\left\{\mathrm{SSi}(\mathrm{O} t \mathrm{Bu})_{3}\right\}_{2}\left(\mathrm{NH}_{3}\right)\left(\mathrm{H}_{2} \mathrm{O}\right)\right](0.127 \mathrm{~g}, 0.1 \mathrm{mmol})$ dissolved in $20 \mathrm{~mL}$ of $n$-hexane (1)-(3) or chloroform (4)-(5), the respective amine [(1) 1,3-propanediamine (0.033 mL, $0.4 \mathrm{mmol}),(\mathbf{2})$ 1,6-hexanediamine (0.046 g, $0.4 \mathrm{mmol})$, (3) 1,7-heptanediamine $(0.061 \mathrm{~mL}, 0.4 \mathrm{mmol}), 1,4-$ butanediamine $(0.041 \mathrm{~mL}, 0.4 \mathrm{mmol}),(4)$ 1,5-pentanediamine $(0.046 \mathrm{~mL}, 0.4 \mathrm{mmol})$ (5)] was added. Resultant mixtures were left at $4{ }^{\circ} \mathrm{C}$ for a few days to yield blue crystals of (1) and (3), deep-violet crystals of complex (2) and deep-violet powders of (4) and (5).

\subsection{1. $\left[\mathrm{Ni}\left\{\left(\mathrm{SSi}(\mathrm{O} t \mathrm{Bu})_{3}\right\}_{2}\left(\mathrm{C}_{3} \mathrm{H}_{10} \mathrm{~N}_{2}\right)_{2}\right]\right.$ (1)}

Anal. Calc. for $\mathrm{C}_{30} \mathrm{H}_{74} \mathrm{~N}_{4} \mathrm{O}_{6} \mathrm{~S}_{2} \mathrm{Si}_{2} \mathrm{Ni}$ : C 47.04; H, 9.74; S, 8.37; N, 7.31\%. Found: C 47.03; H, 9.78; S, 8.36; N, 7.33\%. Yield: $42 \%$, M. p. $196-198{ }^{\circ} \mathrm{C}$. IR (solid state): $v\left[\mathrm{~cm}^{-1}\right]=3324(\mathrm{w})$, 3305 (s), 3274 (s), 3240 (s), 3140 (s), 2967 (vs), 2926 (vs), 2868 (s), 1600 (s), 1469 (s), 1385 (vs), 1358 (vs), 1238 (vs), 1184 (vs), 1113 (m), 1058 (vs), 1032 (s), 1018 (vs), 986 (vs), 903 (s), 814 (s), 799 (s), 682 (s), 648 (s), 628 (w), 551 (s), 491 (m), 417 (w); UV-Vis (solid state): $\lambda_{\max }[\mathrm{nm}]=224,317(\mathrm{br}), 381(\mathrm{sh}), 593,681(\mathrm{sh}), 830$.

\subsection{2. $\left[\mathrm{Ni}\left\{\left(\mathrm{SSi}(\mathrm{O} t \mathrm{Bu})_{3}\right\}_{2}\left(\mu-\mathrm{C}_{6} \mathrm{H}_{16} \mathrm{~N}_{2}\right)_{2}\right]_{\mathrm{n}}(2)\right.$}

Anal. Calc. for $\mathrm{C}_{30} \mathrm{H}_{70} \mathrm{~N}_{2} \mathrm{O}_{6} \mathrm{~S}_{2} \mathrm{Si}_{2} \mathrm{Ni}$ : C 49.09; H, 9.61; S, 8.74; N, 3.82\%. Found: C 48.72; H, 9.57; S, 8.52; N, 3.91\%. Yield: 51\%,M. p. $172-173{ }^{\circ}$ C. IR (solid state): $v\left[\mathrm{~cm}^{-1}\right]=3314(\mathrm{~s})$, 3213 (s), 3123 (s), 2972 (vs), 2929 (vs), 2859 (s), 157 (s), 1459 (s), 1386 (vs), 1361 (vs), 1235 (vs), 1183 (vs), 1138 (w), 1105 (w), 1034 (vs), 1001 (vs), 908 (w), 820 (s), 800 (s), 686 (s), 640 (s), 541 (s), 507 (w), 493 (w), 475 (w), 458 (w), 419 (w); UV-Vis (solid state): $\lambda_{\max }[\mathrm{nm}]$ $=229,255,310,352,527,596(\mathrm{sh})$.

\subsection{3. $\left[\mathrm{Ni}\left\{\left(\mathrm{SSi}(\mathrm{O} t \mathrm{Bu})_{3}\right\}_{2}\left(\mu-\mathrm{C}_{7} \mathrm{H}_{18} \mathrm{~N}_{2}\right)_{4}\right]_{\mathrm{n}}\right.$ (3)}

Anal. Calc. for $\mathrm{C}_{38} \mathrm{H}_{90} \mathrm{~N}_{4} \mathrm{O}_{6} \mathrm{~S}_{2} \mathrm{Si}_{2} \mathrm{Ni}$ : C 51.97; H, 10.33; S, 7.30; N, 7.38\%. Found: C 51.78; H, 10.32; S, 7.11; N, 6.72\%. Yield: 39\%,M. p. 88-89 ${ }^{\circ}$ C. $v\left[\mathrm{~cm}^{-1}\right]=3323$ (s), 3294 (s), 3247 (s), 3144 (w), 2963 (vs), 2919 (vs), 2849 (s), 1583 (m), 1472 (m), 1459 (m), 1383 (s), 1359 (vs), 1235 (vs), 1180 (vs), 1111 (w), 1037 (vs), 1019 (vs), 973 (vs), 907 (m), 812 (s), 798 (s), 679 
(s), $656(\mathrm{~s}), 595(\mathrm{~m}), 548(\mathrm{~s}), 503(\mathrm{w}), 475(\mathrm{~m}), 421(\mathrm{w})$; UV-Vis (solid state): $\lambda_{\max }[\mathrm{nm}]=$ 223, 322, 393 (sh), 617 (br).

\subsection{4. $\left[\mathrm{Ni}\left\{\left(\mathrm{SSi}(\mathrm{O} t \mathrm{Bu})_{3}\right\}_{2}\left(\mu-\mathrm{C}_{4} \mathrm{H}_{12} \mathrm{~N}_{2}\right)_{2}\left(\mathrm{CHCl}_{3}\right)\right]_{\mathrm{n}}\right.$ (4)}

Anal. Calc. for $\mathrm{C}_{29} \mathrm{H}_{67} \mathrm{Cl}_{3} \mathrm{~N}_{2} \mathrm{O}_{6} \mathrm{~S}_{2} \mathrm{Si}_{2} \mathrm{Ni}$ : C 42.21; H, 8.18; S, 7.77; N, 3.39\%. Found: C 42.19; H, 8.19; S, 7.75; N, 3.38\%. Yield: 57\%,M. p. 189-190 ${ }^{\circ} \mathrm{C}$. IR (solid state): $v\left[\mathrm{~cm}^{-1}\right]=3313(\mathrm{~s})$, 3241 (s), 2970 (vs), 2920 (s), 2855 (m), 1567 (m), 1469 (m), 1385 (s), 1361 (vs), 1238 (vs), 1181 (vs), 1128 (m), 1046 (vs), 1036 (vs), 1004 (vs), 965 (w), 909 (w), 823 (s), 801 (s), 691 (s), $643(\mathrm{~s}), 543(\mathrm{~s}), 508(\mathrm{w}), 476(\mathrm{w}), 461(\mathrm{w}), 419(\mathrm{w})$; UV-Vis (solid state): $\lambda_{\max }[\mathrm{nm}]=$ $227,254,319,363,542,604(\mathrm{sh})$.

\subsection{5. $\left[\mathrm{Ni}\left\{\left(\mathrm{SSi}(\mathrm{O} t \mathrm{Bu})_{3}\right\}_{2}\left(\mu-\mathrm{C}_{5} \mathrm{H}_{14} \mathrm{~N}_{2}\right)_{2}\left(\mathrm{CHCl}_{3}\right)\right]_{\mathrm{n}}(\mathbf{5})\right.$}

Anal. Calc. for $\mathrm{C}_{30} \mathrm{H}_{70} \mathrm{Cl}_{3} \mathrm{~N}_{2} \mathrm{O}_{6} \mathrm{~S}_{2} \mathrm{Si}_{2} \mathrm{Ni}$ : C 42.15; H, 8.29; S, 7.76; N, 3.39\%. Found: C 42.18; H, 8.26; S, 7.77; N, 3.31\%. Yield: $21 \%$,M. p. $181-182{ }^{\circ} \mathrm{C}$. IR (solid state): $v\left[\mathrm{~cm}^{-1}\right]=3310$ (m), 3206 (m), 3123 (w), 2969 (vs), 2926 (s), 2864 (m), 1577 (m), 1462 (m), 1458 (m), 1386 (s), 1361 (vs), 1236 (s), 1182 (vs), 1128 (m), 1107 (w), 1035 (vs), 1001 (vs), 908 (w), 820 (s), 800 (s), 686 (s), 641 (s), 542 (s), 505 (w), 474 (w), 459 (w), $419(\mathrm{w})$.

\subsection{Crystallographic data}

The diffraction data were collected on a KUMA KM4 diffractometer employing graphitemonochromated Mo- $\mathrm{K}_{\alpha}$ radiation using a Sapphire-2 CCD detector (Oxford Diffraction Ltd). The apparatus was equipped with an open flow thermostat (Oxford Cryosystems), which enabled experiments at $120 \mathrm{~K}$. The structures were solved with direct methods and refined with the SHELX98 program package with the full-matrix least-squares refinement based on $F^{2}$ [30]. Basic crystal data, description of the diffraction experiment, and details of the structure refinement are given in Table 1. Crystallographic data (without structure factors) for the structures reported in this paper have been deposited with the Cambridge Crystallographic Data Centre with reference number CCDC 838876 (1), 826558 (2) and 838877 (3) can be obtained free of charge via www.ccdc.cam.ac.uk/data_request/cif.

In compounds (1) and (2) the $\mathrm{H}$ atoms were included at the calculated positions $(\mathrm{C}-\mathrm{H}=0.98$ $\AA$ for methyl groups, $\mathrm{C}-\mathrm{H}=0.99 \AA$ for methylene groups and $\mathrm{N}-\mathrm{H}=0.92 \AA$ for amine $\mathrm{H}$ ), and refined using a riding model, with $U$ iso $(\mathrm{H})=1.5 U$ eq $(\mathrm{C})$ (methyl groups), $U$ iso $(\mathrm{H})=$ 1.2Ueq $(\mathrm{C}, \mathrm{N})$ (methylene and amine groups). Compound (2) shows three peaks on the 
difference map in the area of the t-butyl group comprised of C9-C12. It could be explained by some minor disorder in the t-butyl group which was difficult to model.In compound (3) the methylene groups of one of the diamine molecule are disordered over two positions and were refined with an occupancy ratio of 0.65:0.35. All $\mathrm{H}$ atoms in compound (3) were placed in geometrically idealized positions and constrained to ride on their parent atoms $\mathrm{C}-\mathrm{H}=0.98 \AA$ and with $U$ iso $(\mathrm{H})=1.5 U$ eq $(\mathrm{C})$ (methyl groups), $\mathrm{C}-\mathrm{H}=0.99 \AA$ with $U$ iso $(\mathrm{H})=1.2 U \mathrm{eq}(\mathrm{C})$ (methylene groups). $\mathrm{H}$ atoms bonded to $\mathrm{N}$ atoms were located in a difference map and refined

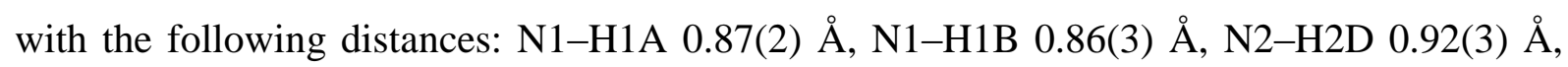
$\mathrm{N} 2-\mathrm{H} 2 \mathrm{E} 0.88(3) \AA$, with $U$ iso $(\mathrm{H})=0.02209 ; 0.03021 ; 0.03428 ; 0.04618 U \mathrm{eq}(\mathrm{N})$ respectively. Crystal data, data collection, and refinement parameters are given in Table 1. Selected bond and angles parameters are given in Table 2.

\section{Results and discussion}

\subsection{Synthesis}

All compounds were synthesized in a simple reaction of the nickel complex $\left[\mathrm{Ni}\left\{\mathrm{SSi}(\mathrm{O} t \mathrm{Bu})_{3}\right\}_{2}\left(\mathrm{NH}_{3}\right)\left(\mathrm{H}_{2} \mathrm{O}\right)\right]$ with the respective diamines. The initial nickel substrate was obtained in a one-step reaction of $\mathrm{NiCl}_{2}$ hexahydrate, tri-tert-butoxysilanethiol and excess of ammonia in aqueous solutions (Fig. 1S Supplementary Materials). The diamines used in this project easily reacted with $\left[\mathrm{Ni}\left\{\mathrm{SSi}(\mathrm{O} t \mathrm{Bu})_{3}\right\}_{2}\left(\mathrm{NH}_{3}\right)\left(\mathrm{H}_{2} \mathrm{O}\right)\right]$ giving single crystals of $\left[\mathrm{Ni}\left\{\left(\mathrm{SSi}(\mathrm{O} t \mathrm{Bu})_{3}\right\}_{2}\left(\mathrm{C}_{3} \mathrm{H}_{10} \mathrm{~N}_{2}\right)_{2}\right] \quad\right.$ (1), $\quad\left[\mathrm{Ni}\left\{\left(\mathrm{SSi}(\mathrm{O} t \mathrm{Bu})_{3}\right\}_{2}\left(\mu-\mathrm{C}_{6} \mathrm{H}_{16} \mathrm{~N}_{2}\right)_{2}\right]_{n} \quad\right.$ (2) and $\left[\mathrm{Ni}\left\{\left(\mathrm{SSi}(\mathrm{O} t \mathrm{Bu})_{3}\right\}_{2}\left(\mu-\mathrm{C}_{7} \mathrm{H}_{18} \mathrm{~N}_{2}\right)_{4}\right]_{n}\right.$ (3) which were suitable for X-ray structure determination. Complexes (1)-(4) are relatively stable under atmospheric conditions, however the melting point of (3) is remarkably low (ca. $89^{\circ} \mathrm{C}$ ). We also noticed that blue crystals of (3) turn into deep-violet during heating or even during grinding. This may suggest a composition and/or coordination geometry change. Obviously, we have tried to recrystallize the obtained violet powder from diverse solvents, but we have not obtained any single crystals. Nevertheless, the elemental analysis of the precipitate pointed at a complex with the formula $\left[\mathrm{Ni}\left\{\left(\mathrm{SSi}(\mathrm{O} t \mathrm{Bu})_{3}\right\}_{2}(1,7 \text {-heptanediamine })_{2}\right]\right.$ and so far we have not been able to decide whether the compound is mononuclear or polynuclear.

The reaction of $\left[\mathrm{Ni}\left\{\mathrm{SSi}(\mathrm{O} t \mathrm{Bu})_{3}\right\}_{2}\left(\mathrm{NH}_{3}\right)\left(\mathrm{H}_{2} \mathrm{O}\right)\right]$ with 1,4-butanediamine and 1,5pentanediamine gave deep-violet powders of (4) and (5) with quite a high yield. The primary characterization of (4) and (5) based on elemental analysis and IR spectroscopy in solid state suggested that both complexes contain tetracoordinated $\mathrm{Ni}(\mathrm{II})$ and have formulas 
$\left[\mathrm{Ni}\left\{\left(\mathrm{SSi}(\mathrm{O} t \mathrm{Bu})_{3}\right\}_{2}(1,4-\text { butanediamine })_{2} \cdot \mathrm{CHCl}_{3}\right]_{n}\right.$

and

$\left[\mathrm{Ni}\left\{\left(\mathrm{SSi}(\mathrm{O} t \mathrm{Bu})_{3}\right\}_{2}(1,5-\right.\right.$ pentanediamine) $\left.)_{2} \cdot \mathrm{CHCl}_{3}\right]_{n}$ (5) (Fig. 2S-3S Suppl. Mat.). We have tried to obtain them as single crystals by repeated recrystallization from various solvents and by changing the initial reaction conditions, but we have not succeeded.

\subsection{Thermal analysis}

We investigated the thermal properties of complex (2) due to its relative stability under atmospheric conditions and its polymeric structure. For our studies we also chose complex (4) as a potentially polymeric construct. The heating rate was maintained at $10{ }^{\circ} \mathrm{C} \cdot \mathrm{min}^{-1}$ from 25 ${ }^{\circ} \mathrm{C}$ to $400{ }^{\circ} \mathrm{C}$. The analysis was carried out under inert atmosphere by flushing argon gas to prevent accumulation of gaseous products. The TG and DTG curves for (2) and (4) are presented in Fig. 6S in Supplementary Materials. The thermogravimetric curves show an obvious weight loss occurring in one step, between 188 and $260{ }^{\circ} \mathrm{C}$ and for (4) and between 180 and $240{ }^{\circ} \mathrm{C}$ for (2). The remaining weight of $10.5 \%$ for (2) and $10.8 \%$ for (4) is likely that of NiS (calcd $12.4 \%$ for (2) and $10.6 \%$ for (4)). Meanwhile, the DTG analysis performed on these two compounds showed that the first decomposition onset for (2) is $197{ }^{\circ} \mathrm{C}$, which is lower than for (4) $207^{\circ} \mathrm{C}$. Next decomposition steps of (2) occur in the range of 219 to 252 ${ }^{\circ} \mathrm{C}$, whereas complex (4) decomposes in the range of $223-235{ }^{\circ} \mathrm{C}$.

FTIR spectra of the off-gases from the decomposition of (2) and (4) complexes are similar and show the presence of the decomposition products of the tri-tert-butoxysilyl substituents (Fig. 7S Suppl. Mat.) which possess both the $\mathrm{Si}-\mathrm{OH}\left(v_{(\mathrm{Si}-\mathrm{O})}=1074 \mathrm{~cm}^{-1}\right)$ and $\mathrm{Si}-\mathrm{O}-t \mathrm{Bu}\left(v_{(\mathrm{C}-}\right.$ o) $=1193 \mathrm{~cm}^{-1}$ ) fragments. Spectra also contain additional bands expected for the symmetric and asymmetric scissor-bending vibrations characteristic for tert-butyl residues (1394 and $\left.1371 \mathrm{~cm}^{-1}\right)$ as well as for $\mathrm{CH}_{2}$ groups of aliphatic carbon chains of diamines $\left(1477 \mathrm{~cm}^{-1}\right)$ and skeleton vibration of the $t \mathrm{Bu}$ group $\left(1241 \mathrm{~cm}^{-1}\right)$.

\subsection{Crystal structures}

Complex (1)

The coordination sphere of nickel ion in compound (1) is comprised of two chelating diamine molecules and two $(t \mathrm{BuO})_{3} \mathrm{SiS}^{-}$residues and adopts a $\mathrm{NiN}_{4} \mathrm{~S}_{2}$ core (Fig. 1). The coordination sphere of the nickel ion can be described as distorted octahedral with trans disposition of $\mathrm{N}$ and S-donor ligands and the $\mathrm{S}(2)-\mathrm{Ni}(1)-\mathrm{S}(1)$ and $\mathrm{N}(1)-\mathrm{Ni}(1)-\mathrm{N}(3)$ angles close to $180^{\circ}$ (Table 2). The degree of the distortion from the ideal octahedral geometry is reflected in the 
cisoid angles ranging from $82.50(17)$ to $94.66(19)^{\circ}$, and the transoid angles $172.2(3)$ $177.2(2)^{\circ}$. The $\mathrm{Ni}-\mathrm{N}$ and $\mathrm{Ni}-\mathrm{S}$ bond distances are in the range 2.078(6)-2.121(7) $\AA$ and 2.5070(19)-2.5741(19) $\AA$, respectively, which are close to those found in other octahedral nickel complexes [27, 31-35]. The spatial arrangement of the ligands leads to the formation of

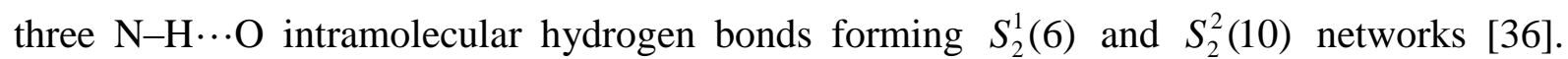
Complex (1) crystallizes as a dimer consisting of two molecules joined by two intermolecular N2-H2B $\cdots \mathrm{S}^{i} \mathrm{~A}^{i}$ and two N3-H3A $\cdots \mathrm{S} 1 \mathrm{~A}^{i}$ hydrogen bonds which form two $R_{2}^{1}(6)$ motifs (Fig. 4S) [36]. Admittedly these interactions are weak $(D \cdots A$ 3.469(7) and 3.687(7) $\AA$, respectively), but still strong enough to form dimers illustrated in Fig. 2. The hydrogen bond distances in such dimers are collected in Table 3.

Compound (2) is polynuclear and crystallizes in the triclinic system, space group $P-1$ with one molecule in the asymmetric unit (Fig. 3). Each Ni(II) atom is surrounded by two nitrogen atoms from two diamine ligands and two sulfur atoms from two silanethiolate residues resulting in the $\mathrm{NiN}_{2} \mathrm{~S}_{2}$ square-planar environment with trans disposition of the ligands around the metal center. The planar geometry on Ni(II) shows some insignificant deviation attributed to the cis $\mathrm{N}-\mathrm{Ni}-\mathrm{S}$ angles (89.10(18) and 90.90(18)) and they are comparable with previously described $\left[\mathrm{Ni}\left\{\mathrm{SSi}(\mathrm{OAr})_{3}\right\}_{2}\left(\mathrm{NH}_{3}\right)_{2}\right]$ [27] but differ by ca. $5^{\circ}$ when compared to similar angles found in $\left[\mathrm{Ni}\left\{\mathrm{SSi}(\mathrm{O} t \mathrm{Bu})_{3}\right\}_{2}\left(\mathrm{C}_{6} \mathrm{H}_{7} \mathrm{~N}\right)_{2}\right]$ [25]. Nevertheless the trans $\mathrm{N}-\mathrm{Ni}-\mathrm{N}$ and $\mathrm{S}-\mathrm{Ni}-\mathrm{S}$ bond angles are all $180^{\circ}$ like in other Ni silanethiolates listed in Table 2 [26-28].

There are many examples of complexes with a $\mathrm{NiN}_{2} \mathrm{~S}_{2}$ core and square planar geometry about nickel ions, but in most cases they are built of bidentate or tetradentate N,S-donor molecules which play the role of chelating or bridging ligands [1-8]. Complexes with terminal N- and Sdonor ligands and square planar coordination geometry on $\mathrm{Ni}$ atoms have $\mathrm{Ni}-\mathrm{N}$ and $\mathrm{Ni}-\mathrm{S}$ bond distances comparable to those present in complex (2) (Table 2) [1-8,26,28,37-40]. The bridging diamine molecules in (2) are arranged in a quite regular manner with all $\mathrm{C}$ atoms in one plane. In the crystal packing they lay parallel and run in one direction (Fig. 5S). The nickel atoms are separated by $11.161 \AA$ within a chain and $14.332 \AA$ between the parallel chains. The inversion center is present in the middle of the $\mathrm{C} 15-\mathrm{C} 15 \mathrm{~A}$ bond of the diamine molecules. Intramolecular hydrogen bonding interactions $\mathrm{N}-\mathrm{H} \cdots \mathrm{O}$ are formed by one hydrogen of each $\mathrm{NH}_{2}$ group of coordinated diamine and oxygen atom of siloxyl residue.

Complex (3) also adopts a polymeric structure. It crystallizes in the triclinic $P-1$ space group with $\mathrm{Ni}$ (II) located at the mid-point of the a-axis, at Wyckoff position $d\left(\frac{1}{2}, 0,0\right)$ (Fig. 4). Each 
octahedral $\mathrm{Ni}(\mathrm{II})$ in (3) is attached to four nitrogen atoms (N(1), $\mathrm{N}(1 \mathrm{~A}), \mathrm{N}(2)$ and $\mathrm{N}(2 \mathrm{~A})$ ) via four bridging diamine molecules and two silanethiolate residues at the axial positions, resulting in a $\mathrm{NiN}_{4} \mathrm{~S}_{2}$ chromophore. The diamine moieties are arranged sinusoidally and form quasi hoops between the metallic centers and their dimensions are 3.123 in the narrowest point and $6.118 \AA$ in the widest point. The coordinated diamine molecules are also engaged in the formation of two intramolecular hydrogen bonds $\mathrm{N}-\mathrm{H} \cdots \mathrm{O}$ to oxygen atoms from adjacent tert-butoxy groups (Table 3).

The chains of (3) run parallel to the crystallographic $a$-axis (Fig. 5). The Ni $\cdots \mathrm{Ni}$ distance between adjacent metal centers within one polymer strand is $11.419 \AA$ while the closest metal-metal distance between two neighboring strands is $9.654 \AA$. The cis $\mathrm{N}-\mathrm{Ni}-\mathrm{N}$ angles are in the range of $86.7(2)-92.8(2)^{\circ}$, whereas the cis $\mathrm{N}-\mathrm{Ni}-\mathrm{S}$ angles span the range of $86.55(7)$ 93.45(7) ${ }^{\circ}$. The $\mathrm{S}(1 \mathrm{~A})-\mathrm{Ni}(1)-\mathrm{S}(1), \mathrm{N}(1)-\mathrm{Ni}(1)-\mathrm{N}(1 \mathrm{~A})$ and $\mathrm{N}(2)-\mathrm{Ni}(1)-\mathrm{N}(2 \mathrm{~A})$ angles in (3) are exactly $180^{\circ}$, unlike those found in the structure of the monomeric complex (1). The Ni-N (2.1284(17) and 2.1615(17) $\AA$ ) and the Ni-S bond distances (2.5045(5) $\AA$ ) are close to those encountered in other octahedral complexes [7,26,27,31-35].

\subsection{Spectral studies}

FT-IR

Vibrational spectra were recorded for crystals of complexes (1)-(5) in the range of 4000-700 $\mathrm{cm}^{-1}$. They exhibit characteristic $\mathrm{NH}_{2}$ group vibrational bands at about 3300 and $3400 \mathrm{~cm}^{-1}$ corresponding to $v_{\mathrm{s}}\left(\mathrm{NH}_{2}\right)$ and $v_{\mathrm{as}}\left(\mathrm{NH}_{2}\right)$, respectively (Fig. 2S, 3S Suppl. Mat.). They also show some differences which come from the presence of various intramolecular $\mathrm{N}-\mathrm{H} \cdots \mathrm{O}$ hydrogen bonds in the crystal structures of (1) and (2) as well as from the intermolecular $\mathrm{N}-$ $\mathrm{H} \cdots \mathrm{S}$ interactions in complex (1) $[37,38]$. Nevertheless they are similar in the region 1100$950 \mathrm{~cm}^{-1}$ (Suppl. Mat. Fig. 3S) where all metal tri-tert-butoxysilanethiolates synthesized so far contain superimposed bands assigned to $\mathrm{Si}-\mathrm{O}-\mathrm{C}$ bonding from silanethiolate residue [23,24, $43,44]$.

$U V$-Vis

The solid-state electronic spectra of (1) and (3) exhibit the presence of d-d broad band in the region at 500-700 $\mathrm{nm} \mathrm{(3),} \mathrm{which} \mathrm{can} \mathrm{be} \mathrm{assigned} \mathrm{to} \mathrm{the} \mathrm{spin} \mathrm{allowed} \mathrm{transitions}$ ${ }^{3} \mathrm{~A}_{2 \mathrm{~g}}(\mathrm{~F}) \rightarrow{ }^{3} \mathrm{~T}_{1 \mathrm{~g}}(\mathrm{~F})$ (using the $\mathrm{O}_{\mathrm{h}}$ labels) which are characteristic for complexes containing an octahedral $\mathrm{d}^{8}$ ion (Fig. 6) [45]. The deviations from octahedral geometry in compound (3) result in a shoulder band at about $700 \mathrm{~nm}$. Additionally, in the spectra of (1) and (3) we 
observe a broad low-intensity band in the region 800-1000 nm, which can be described as unresolved ${ }^{3} \mathrm{~A}_{\mathrm{g}} \rightarrow\left({ }^{3} \mathrm{~B}_{1 \mathrm{~g}},{ }^{3} \mathrm{~B}_{2 \mathrm{~g}},{ }^{3} \mathrm{~B}_{3 \mathrm{~g}}\right)$ transitions [41], where we use $\mathrm{D}_{2 \mathrm{~h}}$ term labeling for consistency with the EPR discussion below. The spectrum of compounds (2) and (4) differs from the above and contains one broad band at higher energy with the maximum at about 540 $\mathrm{nm}$ which can be ascribed to the ${ }^{1} \mathrm{~A}_{\mathrm{g}} \rightarrow{ }^{1} \mathrm{~B}_{\mathrm{g}}$ transition $\left(x^{2}-y^{2} \rightarrow z^{2}\right)$ characteristic for square planar Ni(II) complexes [6;47,48]. The UV region shows strong absorptions at about 224 and $317 \mathrm{~nm}$ (1), 229, 255, 310 and 352nm (2), 223 and $322 \mathrm{~nm} \mathrm{(3),} \mathrm{227,} \mathrm{254,} 319$ and $363 \mathrm{~nm}$ (4). These absorptions can be assigned to the typical intraligand $\mathrm{L} \rightarrow \mathrm{L}^{*}$ transitions and to $\mathrm{L} \rightarrow \mathrm{M}$ charge transfer. The second absorption band is more intense than the first one which is assigned as a $\mathrm{S} \rightarrow \mathrm{Ni} \mathrm{CT}[46-49]$.

\section{$H F E P R$}

The monomeric complex (1) exhibited well resolved high-field EPR spectra at low temperatures (Fig. 7-8). Spectra of other complexes were not interpretable, exhibiting very broad unresolved features. The spectra of (1) were interpreted by using the spin Hamiltonian for $S=1$

$$
\hat{\boldsymbol{H}}=\mu_{\mathrm{B}} \boldsymbol{B} \cdot\{\boldsymbol{g}\} \cdot \hat{\boldsymbol{S}}+D\left\{\hat{\boldsymbol{S}}_{\mathrm{z}}^{2}-S(S+1) / 3\right\}+E\left(\hat{\boldsymbol{S}}_{\mathrm{x}}^{2}-\hat{\boldsymbol{S}}_{\mathrm{y}}{ }^{2}\right)
$$

Spectra were successfully simulated using the parameter set $g_{\mathrm{x}}=2.191, g_{\mathrm{y}}=2.202, g_{\mathrm{z}}=2.143$, $D=7.596 \mathrm{~cm}^{-1}, E=0.576 \mathrm{~cm}^{-1}$. With the zero-field splitting this large, no transitions below 2.5 $\mathrm{T}$ would be observed in $\mathrm{X}$ Band $(9.6 \mathrm{GHz})$, while the $\Delta \mathrm{M}_{\mathrm{S}}=2$ transition should be present at $0.12 \mathrm{~T}$ in Q-Band (35 GHz), with no other transitions below 4.5T. Standard X and Q Band EPR spectrometers are not equipped with magnets this strong. An additional advantage of the high-field EPR spectroscopy is the possibility of determining the sign of the zero-field splitting parameters $D$ and $E$. [17-20,50,51]. Although the positions of the resonance lines do not depend on the sign of $D$, the intensity patterns in the low-temperature high-field spectra depend on it. Positive signs of $D$ and $E$ could be determined by analysis of a $304.8 \mathrm{GHz}$ spectrum recorded at $5 \mathrm{~K}$ (Fig. 7). Both negative [20] and positive $D$ [18] were found previously from HF EPR of Ni(II) complexes. Positive $D$ and $g_{\mathrm{x}}, g_{\mathrm{y}}>g_{\mathrm{z}}$ are characteristic for $\mathrm{Ni}^{2+}$ in elongated octahedral coordination $[52,53]$. Both negative $[18,20,54]$ and positive $D$ [16] were found previously from HF EPR of pseudooctahedral Ni(II) complexes. The EPR $g$ values in hexacoordinated $\mathrm{Ni}^{2+}$ complexes with distorted octahedral environment are related to the ${ }^{3} \mathrm{~A}_{\mathrm{g}} \rightarrow{ }^{3} \mathrm{~B}_{1 \mathrm{~g}},{ }^{3} \mathrm{~A}_{\mathrm{g}} \rightarrow{ }^{3} \mathrm{~B}_{2 \mathrm{~g}}$ and ${ }^{3} \mathrm{~A}_{\mathrm{g}} \rightarrow{ }^{3} \mathrm{~B}_{3 \mathrm{~g}}$ transition energies (using $\mathrm{D}_{2 \mathrm{~h}}$ labeling, see Fig 9), as are the zero-field splitting tensor components $D_{\mathrm{xx}}$ etc.[52]: 


$$
\begin{array}{ll}
g_{x}=g_{e}-\frac{8 \lambda k_{x}^{2}}{E\left({ }^{3} B_{3 g}\right)-E\left({ }^{3} A_{g}\right)}, & D_{x x}=\frac{-4 \lambda^{2} k_{x}^{2}}{E\left({ }^{3} B_{3 g}\right)-E\left({ }^{3} A_{g}\right)} \\
g_{y}=g_{e}-\frac{8 \lambda k_{y}^{2}}{E\left({ }^{3} B_{2 g}\right)-E\left({ }^{3} A_{g}\right)}, & D_{y y}=\frac{-4 \lambda^{2} k_{y}^{2}}{E\left({ }^{3} B_{2 g}\right)-E\left({ }^{3} A_{g}\right)} \\
g_{z}=g_{e}-\frac{8 \lambda k_{z}^{2}}{E\left({ }^{3} B_{1 g}\right)-E\left({ }^{3} A_{g}\right)}, & D_{y y}=\frac{-4 \lambda^{2} k_{z}^{2}}{E\left({ }^{3} B_{1 g}\right)-E\left({ }^{3} A_{g}\right)}
\end{array}
$$

where the spin-orbit coupling constant $\lambda$ equals $-315 \mathrm{~cm}^{-1}$ [52] and $k_{\mathrm{x}}, k_{\mathrm{y}}, k_{\mathrm{z}}$ are the orbital reduction factors. It is seen that $D_{\mathrm{xx}}=-\lambda\left(g_{\mathrm{x}}-g_{\mathrm{e}}\right) / 2$ etc. An approximate relationship between $D, E$ and the g components can thus be derived. Using the relations between the tensor components $D_{\mathrm{ii}}$ and the $D$ and $E$ parameters of the spin Hamiltonian (1):

$$
D=\left(2 D_{\mathrm{zz}}-D_{\mathrm{xx}}-D_{\text {yy }}\right) / 2, \quad E=\left(D_{\mathrm{xx}}-D_{\mathrm{yy}}\right) / 2
$$

one obtains

$$
D=\lambda\left(g_{\mathrm{z}}-g_{\mathrm{x}} / 2-\mathrm{g}_{\mathrm{y}} / 2\right) / 2, \quad E=\lambda\left(g_{\mathrm{x}}-\mathrm{g}_{\mathrm{y}}\right) / 4
$$

The three electronic transitions are not resolved in the electronic spectra of (1). Only a broad band is seen with barely distinguishable saddle point in its middle. We will therefore treat the low-energy side of that band at $11600 \mathrm{~cm}^{-1}$ as an average of the ${ }^{3} \mathrm{~A}_{\mathrm{g}} \rightarrow{ }^{3} \mathrm{~B}_{2 \mathrm{~g}}$ and ${ }^{3} \mathrm{~A}_{\mathrm{g}} \rightarrow{ }^{3} \mathrm{~B}_{3 \mathrm{~g}}$ transition energies, while the high-energy end at $12300 \mathrm{~cm}^{-1}$ will be assigned to the ${ }^{3} \mathrm{~A}_{\mathrm{g}} \rightarrow$ ${ }^{3} \mathrm{~B}_{1 \mathrm{~g}}$ transition. The parameters found here, $\left(D=7.596 \mathrm{~cm}^{-1}, E=0.576 \mathrm{~cm}^{-1}\right)$ obey relationship (3) - when using $g_{\mathrm{x}}=2.191, g_{\mathrm{y}}=2.202, g_{\mathrm{z}}=2.143$, we get $D=+8.42 \mathrm{~cm}^{-1}, \mathrm{E}=0.87 \mathrm{~cm}^{-1}$, in a reasonable agreement. Also, the orbital reduction factors $k_{\mathrm{x}}^{2} \approx k_{\mathrm{y}}^{2}=0.89, k_{\mathrm{z}}^{2}=0.66$ can be determined from the $g$ component magnitudes (Table 4). The latter are not significantly changed when the band center only is used for all three transitions ${ }^{3} \mathrm{~A}_{\mathrm{g}} \rightarrow{ }^{3} \mathrm{~B}_{2 \mathrm{~g}}$ and ${ }^{3} \mathrm{~A}_{\mathrm{g}} \rightarrow{ }^{3} \mathrm{~B}_{3 \mathrm{~g}}$ and ${ }^{3} \mathrm{~A}_{\mathrm{g}} \rightarrow{ }^{3} \mathrm{~B}_{1 \mathrm{~g}}$. One should bear in mind that formulas (2) reflect only the spin-orbit coupling contributions to the zero-field splitting tensor components, while the dipole-dipole interactions are ignored, as are also the contributions due to the higher excited ligand-field states [19b]. Data in Table 4 illustrate difficulties in interpretation of the magnitude and even sign of $D$ in the pseudo-octahedral nickel complexes and also show that eq (4) is not in general obeyed, as the symmetry of the $g$ matrix is not always related to the symmetry of the zero-field splitting. For example, in $\left[\mathrm{Ni}-\left(\mathrm{HIM}_{2}-\mathrm{py}\right)_{2} \mathrm{NO}_{3}\right] \mathrm{NO}_{3}$, [55] the isotropic $g$ is accompanied by a very large $D$. Two very similar complexes $[\mathrm{Ni}(\mathbf{L} 1)]\left(\mathrm{PF}_{6}\right)_{2}$ and $[\mathrm{Ni}(\mathbf{L} 1)]\left(\mathrm{PF}_{6}\right)_{2}[56]$ exhibit almost the same $g$ values, but differ in the sign of $D$ (Table 4). 
This has been proven by theoretical calculations to be due to the $\mathrm{Z}$ axis reorientation caused by subtle structural differences. It should be emphasized at this point that the $\mathrm{Z}$ axis orientation has not been experimentally determined for any of the complexes in Table 4, and probably not for any other ones, as only powder EPR data are available. The experimental $g$ components are typically arranged so that the "most distinguished" one is called $\mathrm{g}_{\mathrm{z}}$. When doing so, it is not always possible to achieve the standard EPR convention, $E<D / 3$. For $\mathrm{Ni}(\mathrm{CMA})_{2}(\mathrm{Im})_{2} \bullet(\mathrm{MeOH})_{2}[16]$, the convention is achieved when $g_{\mathrm{z}}=2.13$ is chosen, while the "most distinguished" $g$ component is 2.29 (Table 4). When the $g_{\mathrm{x}}$ and $g_{\mathrm{z}}$ values in Table 4 for this complex are swapped, the parameter set can be transformed to $g_{\mathrm{x}}=2.13, g_{\mathrm{y}}=2.18, g_{\mathrm{z}}$ $=2.29, D=-0.4305 \mathrm{~cm}^{-1}, E=3.702 \mathrm{~cm}^{-1}$, which while being unconventional, is fully equivalent to that in Table 4 and will result in the same EPR simulations (Fig 8S Supplementary Materials) and calculated magnetic properties. Less trouble is expected when an approximately tetragonal, rather than strongly rhombic, distortion is present. Complexes (1), $\left\{\mathrm{Ni}(\mathrm{L}-\mathrm{tyr})_{2}\left(\mu-4,4^{\prime}-\text { bpy }\right) \bullet 4 \mathrm{H}_{2} \mathrm{O}\right\}_{\mathrm{n}}$ and $\mathrm{Ni}(\mathrm{Im})_{2}(\mathrm{~L}-\text { tyr })_{2} \bullet 4 \mathrm{H}_{2} \mathrm{O}$ in Table 4 exhibit an approximately axial $g$ matrix $\left(g_{\mathrm{x}} \approx g_{\mathrm{y}}\right)$ and the trans $-\mathrm{NiN}_{4} \mathrm{~S}_{2}$ chromophore in (1) appears to be an analogue of trans $-\mathrm{NiN}_{2} \mathrm{~N}_{2} \mathrm{O}_{2}$ in $\left\{\mathrm{Ni}(\mathrm{L}-\mathrm{tyr})_{2}(\mu-4,4 \text { '-bpy }) \cdot 4 \mathrm{H}_{2} \mathrm{O}\right\}_{\mathrm{n}}$. The latter compound has negative $D$ and the trend of its $g$ components $-g_{\mathrm{z}}$ larger than $g_{\mathrm{x}, \mathrm{y}}$, is opposite to (1). Also, the pattern of the orbital reduction factors is reversed (Table 4). Low value of $k_{z}^{2}$ in (1) can probably be attributed to the presence of strongly electron delocalizing sulfur ligands on the $\mathrm{Z}$ axis.

\section{Conclusions}

We report here the synthesis and characterization of novel heteroleptic $\mathrm{Ni}$ (II) silanethiolate complexes containing diverse aliphatic diamines and $\mathrm{NiN}_{2} \mathrm{~S}_{2}$ and $\mathrm{NiN}_{4} \mathrm{~S}_{2}$ chromophores. Compounds were characterized by single crystal X-ray diffraction, IR and UV-Vis spectra, elemental and TG analysis, and HFEPR measurements. The electronic spectroscopy data successfully correlate to crystallographic results obtained for (1)-(3) and give valuable insight into their features. The structures of the remaining compounds (4) and (5) have not been possible to determine by X-ray diffraction due to the lack of suitable crystals. However the results of elemental and spectral analysis suggest the presence of a tetracoordinated $\mathrm{N}_{2} \mathrm{~S}_{2}$ environment on $\mathrm{Ni}^{2+}$ centers. The monomeric complex (1) exhibits well resolved high-field EPR spectra at low temperatures. As far as the authors are aware, these are the first described results of HFEPR measurement obtained for octahedral $\mathrm{Ni}(\mathrm{II})$ complexes containing silanethiolate as well as thiolate $\mathrm{RS}^{-}$ligands. 


\section{Acknowledgements}

We gratefully acknowledge financial support from the Polish Ministry of Science and Higher Education Grant No. N N204 155940. The high-field EPR spectra were recorded at the NHMFL, which is funded by the NSF through the Cooperative Agreement No. DMR1157490, the State of Florida and the DOE. A. P. also thanks Professor Julia Jezierska for help.

\section{References}

[1] Ø. Hatlevik, M. C. Blanksma, V. Mathrubootham, A. M. Arif, E. L. Hegg, J. Biol. Inorg. Chem. 9 (2004) 238-246.

[2] T. C. Harrop, P. K. Mascharak, Coord. Chem. Rev. 249 (2005) 3007-3024.

[3] T. C. Harrop, M. M. Olmstead, P. K. Mascharak, Inorg. Chem. 45 (2006) 3424-3436.

[4] E. M. Gale, D. M. Cowart, R. A. Scott, T. C Harrop, Inorg. Chem. 50 (2011) 1046010471.

[5] J. R. Zimmerman, B. W. Smucker, R. P. Dain, M. J. Van Stipdonk, D. M. Eichhorn, Inorg. Chim. Acta 373 (2011) 54-61.

[6] E. P. Broering, P. T. Truong, E. M. Gale, T. C. Harrop, Biochemistry 52 (2013) 4-18.

[7] J. A. Denny, M. Y. Darensbourg, Chem. Rev. 115 (2015) 5248-5273.

[8] H.-J. Krüger, G. Peng, R. H. Holm, Inorg. Chem. 31 (1991) 734-742; M. A. Ali, A. H. Mirza, C. C. Mei, P. V. Bernhardt, M. R. Karim, Polyhedron 49 (2013) 277-283.

[9] M. Neurock, R. A. Van Santen, J. Am. Chem. Soc. 116 (1994) 4427-4439.

[10] D. L. Hoang, S. H. Chan, O. L. Ding, Power Sources 159 (2006) 1248-1257.

[11] A. Ghezelbash, M. B. Sigman, B. A. Korgel, Nano Lett. 4 (2004) 537-542.

[12] K.-Y. Choi, J. Chem. Crystallogr. 40 (2010) 477-481.

[13] Y. Zhao, M. Hong, Y. Liang, R. Cao, W. Li, J. Weng, S. Lu, Chem. Commun. (2001) 1020-1021.

[14] S. Petit, P. Neugebauer, G. Pilet, G. Chastanet, A.-L. Barra, A. B. Antunes, W. Wernsdorfer, D. Luneau, Inorg. Chem. 51 (2012) 6645-6654.

[15] B. Żurowska, J. Mroziński, M. Julve, F. Lloret, A. Maslejova, W. Sawka-Dobrowolska, Inorg. Chem. 41 (2002) 1771-1777.

[16] J. Krzystek, A. Ozarowski, J. Telser, Coord. Chem. Rev. 250 (2006) 2308-2324. 
[17] D. Dobrzyńska, L. B. Jerzykiewicz, M. Duczmal, A. Wojciechowska, K. Jabłońska, J. Palus, A. Ozarowski, Inorg. Chem. 45 (2006) 10479-10486.

[18] A. Wojciechowska, M. Daszkiewicz, Z. Staszak, A. Trusz-Zdybek, A. Bieńko, A. Ozarowski, Inorg. Chem. 50 (2011) 11532-11542.

[19] (a) P. J. Desrochers, C. A. Sutton, M. L. Abrams, S. Ye, F. Neese, J. Telser, A. Ozarowski, J. Krzystek, Inorg. Chem. 51 (2012) 2793-2805. (b) S. Ye, F. Neese, Chem. Theory Comput. 8 (2012) 2344-2351.

[20] A. Wojciechowska, A. Gągor, M. Duczmal, Z. Staszak, A. Ozarowski, Inorg. Chem. 52 (2013) 4360-4371.

[21] I. G. Dance, Polyhedron 5 (1986) 1037-1104.

[22] A. Pladzyk, Z. Hnatejko, K. Baranowska, Polyhedron 79 (2014) 116-123 and the references therein.

[23] A. Pladzyk, K. Baranowska, J Mol. Struct. 1058 (2014) 252-258.

[24] A. Dołęga, Coord. Chem. Rev. 254 (2010) 916-937 and the references therein.

[25] R. Piękoś, W. Wojnowski, Z. Anorg. Allg. Chem. 318 (1962) 212-216; A. Herman, B. Becker, W. Wojnowski, Z. Anorg. Allg. Chem. 450 (1979) 178-182.

[26] Ł. Ponikiewski, A. Pladzyk, W. Wojnowski, B. Becker, Polyhedron 30 (2011) 24002405.

[27] A. Pladzyk, Ł. Ponikiewski, Y. Lan, A. K. Powell, Inorg. Chem. Comm. 20 (2012) 6669.

[28] A. Dołęga, A. Jabłońska, A. Pladzyk, Ł. Ponikiewski, W. Ferenc, J. Sarzyński, A. Herman, Dalton Trans. 43 (2014) 12766-12775.

[29] A. K. Hassan, L. A. Pardi, J. Krzystek, A. Sienkiewicz, P. Goy, M. Rohrer, L.-C. Brunel, J. Magn. Reson. 142 (2000) 300-312.

[30] G. M. Sheldrick Acta Crystallogr., Sect. A Found Crystallogr. 64 (2008) 112-122.

[31] T. Rojo, R. Corte's, L. Lezama, M. I. Arriortua, K. Urtiaga, G. Willeneuve, J. Chem. Soc., Dalton Trans. (1991) 1779-1783.

[32] M. Monfort, J. Ribas, X. Solans, Inorg. Chem. 33 (1994) 4271-4276.

[33] S. G. Rosenfield, H. P. Berends, L. Gelmini, D. W. Stephan, P. K. Mascharak, Inorg. Chem. 26 (1987) 2792-2797.

[34] N. de Vries, J. Reedijk, Inorg. Chem. 30 (1991) 3700-3703.

[35] P. Stavropoulos, M. C. Muetterties, M. Carrie, R. H. Holm, J. Am. Chem. Soc. 113 (1991) 8485-8492. 
[36] M. C. Etter , J. C. MacDonald, Acta Crystallogr., Sect. B 46 (1990) 256-262; J. Bernstein, R. E. Davis, L. Shimoni, N.-L. Chang, Angew. Chem., Int. Ed. 34 (1995) 1555-1573.

[37] T. Komuro, H. Kawaguchi, K. Tatsumi, Inorg. Chem. 41 (2002) 5083-5090.

[38] M. Ito, M. Kotera, T. Matsumoto, K. Tatsumi, PNAS 106 (2009) 11862-11866.

[39] E. M. Gale, A. K. Patra, T. C. Harrop, Inorg. Chem. 48 (2009) 5620-5622.

[40] E. M. Gale, B. S. Narendrapurapu, A. C. Simmonett, H. F. Schaefer III, T. C. Harrop, Inorg. Chem. 49 (2010) 7080-7096.

[41] I. Nakagawa, R. J. Hooper, J. L. Walter, T. J. Lane, Spectrochim. Acta 21 (1965) 1-14.

[42] K. Nakamoto, Infrared and Raman Spectra of Inorganic and Coordination Compounds, John Wiley \& Sons, Inc. (1997).

[43] A. Dołęga, B. Becker, J. Chojnacki, A. Konitz, W. Wojnowski, Inorg. Chim. Acta 357 (2004) 461-467.

[44] A. Dołęga, A. Ciborska, j. Chojnacki, M. Walewski, W. Wojnowski, Thermochimica Acta 429 (2005) 103-109.

[45] L. Wang, J. Cai, Z.-W. Mao, X.-L. Feng, J.-W. Huang, Trans. Met. Chem. 29 (2004) 411-418.

[46] A. F. Schreiner, D. J. Hamm, Inorg. Chem.12 (1973) 2037-2048.

[47] A. B. P. Lever, Inorganic Electronic Spectroscopy, second ed., Elsevier Science Publishing Co., Inc. New York, (1984).

[48] A. R. Latham, V. C. Hascall, H. B. Gray, Inorg. Chem. 4 (1965) 788-792.

[49] A. T. Fiedler, P. A. Bryngelson, M. J. Maroney, T. C. Brunold, J. Am. Chem. Soc. 127 (2005) 5449-5462.

[50] A. Ozarowski, Inorg. Chem. 47 (2008) 9760-9762.

[51] A. Ozarowski, I. B. Szymańska, T. Muziol, J. Jezierska, J. Am. Chem. Soc. 131 (2009) 10279-10292;

[52] R. Boča, Struct. Bond. 117 (2006) 1-264.

[53] R. Boča, Coord Chem. Rev. 248 (2004) 757-815.

[54] A. Wojciechowska, J. Janczak, Z. Staszak, M. Duczmal, W. Zierkiewicz, J. Tokar, A. Ozarowski, New. J. Chem., 39 (2015) 6813-6822.

[55] G. Rogez, J. N. Rebilly, A. L. Barra, L. Sorace, G. Blondin, N. Kirchner, M. Duran, L. Ricard, A. Marvilliers, T. Mallah, Angew. Chem. Int. Ed. 44 (2005) 1876-1879.

[56] G. Charron, F. Bellot, F. Cisnetti, G. Pelosi, J. N. Rebilly, E. Riviere, A. L. Barra, T. Mallah, C. Policar, Chem. Eur. J. 13 (2007) 2774-2782. 
Table 1 Crystallographic data and structure refinement for (1)-(3) complexes

\begin{tabular}{|c|c|c|c|}
\hline & (1) & (2) & (3) \\
\hline Empirical formula & $\mathrm{C}_{30} \mathrm{H}_{74} \mathrm{~N}_{4} \mathrm{O}_{6} \mathrm{~S}_{2} \mathrm{Si}_{2} \mathrm{Ni}$ & $\mathrm{C}_{30} \mathrm{H}_{70} \mathrm{~N}_{2} \mathrm{O}_{6} \mathrm{~S}_{2} \mathrm{Si}_{2} \mathrm{Ni}$ & $\mathrm{C}_{38} \mathrm{H}_{90} \mathrm{~N}_{4} \mathrm{O}_{6} \mathrm{~S}_{2} \mathrm{Si}_{2} \mathrm{Ni}$ \\
\hline$M_{\mathrm{r}} / \mathrm{g} \mathrm{mol}^{-1}$ & 765.94 & 733.89 & 878.15 \\
\hline Temperature /K & $120(2)$ & $120(2)$ & $120(2)$ \\
\hline Wavelength $/ \AA$ & 0.71073 & 0.71073 & 0.71073 \\
\hline Crystal system & monoclinic & triclinic & triclinic \\
\hline Space group & $P 2_{1} / \mathrm{n}$ & $P-1$ & $P-1$ \\
\hline $\begin{array}{l}\text { Unit cell dimensions / A, } \\
a\end{array}$ & 13.7931(7) & $8.7740(6)$ & $9.6544(4)$ \\
\hline$b$ & $12.4749(6)$ & $9.3769(9)$ & $10.2058(4)$ \\
\hline$c$ & $25.3305(12)$ & $14.3325(13)$ & $14.2556(5)$ \\
\hline$\alpha$ & 90 & $99.828(8)$ & $101.887(3)$ \\
\hline$\beta$ & $94.231(4)$ & $102.707(7)$ & $99.904(3)$ \\
\hline & 90 & $104.192(7)$ & $109.865(3)$ \\
\hline$V / \AA^{3}$ & $4346.7(4)$ & $1083.28(16)$ & $1247.22(8)$ \\
\hline & 4 & 1 & 1 \\
\hline$D_{c} / \mathrm{Mg} \mathrm{m}^{-3}$ & 1.170 & 1.125 & 1.169 \\
\hline$\theta$ range $/^{\circ}$ & 2.67 to 26.00 & 2.43 to 25.00 & 2.21 to 26.00 \\
\hline Limiting indices & $\begin{array}{l}-11<=\mathrm{h}<=17 \\
8<-\mathrm{k}<-15\end{array}$ & $-10<=\mathrm{h}<=10$ & $-11<=\mathrm{h}<=11$ \\
\hline & $\begin{array}{l}-8<=k<=15 \\
-29<=1<=31\end{array}$ & $\begin{array}{l}-11<=\mathrm{k}<=9 \\
-16<=1<=17\end{array}$ & $\begin{array}{l}-12<=\mathrm{k}<=10 \\
-9<-1<-17\end{array}$ \\
\hline Reflections collected / unique & $15900 / 8471$ & $5862 / 3774$ & $8159 / 4879$ \\
\hline & {$[R($ int $)=0.0763]$} & $[R$ (int $)=0.0479]$ & $[R$ (int $)=0.0294]$ \\
\hline Completeness to $\theta_{\max } / \%$ & 99.3 & 99.0 & 99.8 \\
\hline Absorption coefficient $\left(\mathrm{mm}^{-1}\right)$ & 0.637 & 0.635 & 0.563 \\
\hline Data / restraints / parameters & $8471 / 0 / 376$ & 3774 / 0 / 211 & 4879 / 0 / 256 \\
\hline Goodness-of-fit on $F^{2}$ & 1.176 & 1.065 & 1.044 \\
\hline Final $R$ indices $[I>2 \sigma(I)]$ & $\begin{array}{l}R 1=0.0876 \\
w R 2=0.1990\end{array}$ & $\begin{array}{l}R 1=0.0748 \\
w R 2=0.1773\end{array}$ & $\begin{array}{l}R 1=0.0384 \\
w R 2=0.0986\end{array}$ \\
\hline$R$ indices (all data) & $R l=0.1519$ & $R l=0.0985$ & $R l=0.0506$ \\
\hline & $w R 2=0.2279$ & $w R 2=0.1844$ & $w R 2=0.1029$ \\
\hline $\begin{array}{l}\text { Largest diff. peak and hole /eA } \\
\text { CCDC number }\end{array}$ & $\begin{array}{l}0.889 \text { and }-0.803 \\
838876\end{array}$ & $\begin{array}{l}1.422 \text { and }-0.520 \\
826558\end{array}$ & $\begin{array}{l}0.664 \text { and }-0.305 \\
838877\end{array}$ \\
\hline
\end{tabular}


Table 2 Selected interatomic distances $(\AA)$ and angles $\left({ }^{\circ}\right)$ for $(\mathbf{1})-(\mathbf{3})$

\begin{tabular}{|c|c|c|c|c|c|}
\hline \multirow{2}{*}{\multicolumn{2}{|c|}{ (1) }} & \multicolumn{2}{|l|}{ (2) } & \multicolumn{2}{|l|}{ (3) } \\
\hline & & & & & \\
\hline $\mathrm{Ni}(1)-\mathrm{N}(1)$ & $2.078(6)$ & $\mathrm{Ni}(1)-\mathrm{N}(1)$ & $1.907(5)$ & $\mathrm{Ni}(1)-\mathrm{N}(1)$ & $2.1284(17)$ \\
\hline $\mathrm{Ni}(1)-\mathrm{N}(2)$ & $2.107(9)$ & & & $\mathrm{Ni}(1)-\mathrm{N}(2)$ & $2.1615(17)$ \\
\hline $\mathrm{Ni}(1)-\mathrm{N}(3)$ & $2.121(6)$ & & & & \\
\hline $\mathrm{Ni}(1)-\mathrm{N}(4)$ & $2.121(7)$ & & & & \\
\hline $\mathrm{Ni}(1)-\mathrm{S}(1)$ & $2.5070(19)$ & $\mathrm{Ni}(1)-\mathrm{S}(1)$ & $2.2472(15)$ & $\mathrm{Ni}(1)-\mathrm{S}(1)$ & $2.5045(5)$ \\
\hline $\mathrm{Ni}(1)-\mathrm{S}(2)$ & $2.5741(19)$ & & & & \\
\hline $\mathrm{Si}(1)-\mathrm{S}(1)$ & $2.064(3)$ & $\mathrm{Si}(1)-\mathrm{S}(1)$ & $2.085(2)$ & & \\
\hline $\mathrm{Si}(2)-\mathrm{S}(2)$ & $2.055(3)$ & & & & \\
\hline $\mathrm{Si}(1)-\mathrm{O}(1)$ & $1.655(5)$ & $\mathrm{Si}(1)-\mathrm{O}(1)$ & $1.627(4)$ & $\mathrm{Si}(1)-\mathrm{O}(1)$ & $1.6348(15)$ \\
\hline $\mathrm{Si}(1)-\mathrm{O}(2)$ & $1.645(5)$ & $\mathrm{Si}(1)-\mathrm{O}(2)$ & $1.621(4)$ & $\mathrm{Si}(1)-\mathrm{O}(2)$ & $1.6606(15)$ \\
\hline $\mathrm{Si}(1)-\mathrm{O}(3)$ & $1.641(5)$ & $\mathrm{Si}(1)-\mathrm{O}(3)$ & $1.637(4)$ & $\mathrm{Si}(1)-\mathrm{O}(3)$ & $1.6397(14)$ \\
\hline $\mathrm{Si}(2)-\mathrm{O}(4)$ & $1.656(5)$ & & & & \\
\hline $\mathrm{Si}(2)-\mathrm{O}(5)$ & $1.638(5)$ & & & & \\
\hline $\mathrm{Si}(2)-\mathrm{O}(6)$ & $1.642(5)$ & & & & \\
\hline \multicolumn{6}{|l|}{ Bond angles [deg] } \\
\hline $\mathrm{N}(1)-\mathrm{Ni}(1)-\mathrm{N}(2)$ & $90.9(2)$ & $\mathrm{N}(1)-\mathrm{Ni}(1)-\mathrm{N}(1)^{a}$ & 180 & $\mathrm{~N}(1)-\mathrm{Ni}(1)-\mathrm{N}(1)^{b}$ & $180.00(13)$ \\
\hline $\mathrm{N}(1)-\mathrm{Ni}(1)-\mathrm{N}(4)$ & $86.8(2)$ & & & $\mathrm{N}(1)-\mathrm{Ni}(1)-\mathrm{N}(2)$ & $93.45(7)$ \\
\hline $\mathrm{N}(2)-\mathrm{Ni}(1)-\mathrm{N}(4)$ & $172.2(3)$ & & & $\mathrm{N}(1)-\mathrm{Ni}(1)-\mathrm{N}(2)^{c}$ & $86.55(7)$ \\
\hline $\mathrm{N}(1)-\mathrm{Ni}(1)-\mathrm{N}(3)$ & $177.2(2)$ & & & $\mathrm{N}(2)-\mathrm{Ni}(1)-\mathrm{N}(2)^{c}$ & 180 \\
\hline $\mathrm{N}(2)-\mathrm{Ni}(1)-\mathrm{N}(3)$ & $89.2(2)$ & & & & \\
\hline $\mathrm{N}(4)-\mathrm{Ni}(1)-\mathrm{N}(3)$ & $92.8(3)$ & & & & \\
\hline $\mathrm{N}(1)-\mathrm{Ni}(1)-\mathrm{S}(1)$ & $92.93(18)$ & $\mathrm{N}(1)-\mathrm{Ni}(1)-\mathrm{S}(1)$ & $89.10(18)$ & $\mathrm{N}(1)-\mathrm{Ni}(1)-\mathrm{S}(1)$ & 92.74(5) \\
\hline $\mathrm{N}(2)-\mathrm{Ni}(1)-\mathrm{S}(1)$ & 92.83(19) & $\mathrm{N}(1)-\mathrm{Ni}(1)-\mathrm{S}(1)^{a}$ & $90.90(18)$ & $\mathrm{N}(1)-\mathrm{Ni}(1)-\mathrm{S}(1)^{b}$ & $87.26(5)$ \\
\hline $\mathrm{N}(3)-\mathrm{Ni}(1)-\mathrm{S}(1)$ & $89.88(18)$ & & & $\mathrm{N}(2)-\mathrm{Ni}(1)-\mathrm{S}(1)^{c}$ & $93.10(5)$ \\
\hline $\mathrm{N}(4)-\mathrm{Ni}(1)-\mathrm{S}(1)$ & $94.70(19)$ & & & $\mathrm{N}(2)-\mathrm{Ni}(1)-\mathrm{S}(1)^{d}$ & $86.90(5)$ \\
\hline $\mathrm{N}(1)-\mathrm{Ni}(1)-\mathrm{S}(2)$ & $94.70(18)$ & & & & \\
\hline $\mathrm{N}(2)-\mathrm{Ni}(1)-\mathrm{S}(2)$ & 87.44(19) & & & & \\
\hline $\mathrm{N}(3)-\mathrm{Ni}(1)-\mathrm{S}(2)$ & $82.50(17)$ & & & & \\
\hline $\mathrm{N}(4)-\mathrm{Ni}(1)-\mathrm{S}(2)$ & $85.36(19)$ & & & & \\
\hline $\mathrm{S}(2)-\mathrm{Ni}(1)-\mathrm{S}(1)$ & $172.37(7)$ & $\mathrm{S}(1)-\mathrm{Ni}(1)-\mathrm{S}(1)^{a}$ & 180 & $\mathrm{~S}(1)-\mathrm{Ni}(1)-\mathrm{S}(1)^{b}$ & 180 \\
\hline $\mathrm{Si}(1)-\mathrm{S}(1)-\mathrm{Ni}(1)$ & $111.70(9)$ & $\mathrm{Si}(1)-\mathrm{S}(1)-\mathrm{Ni}(1)$ & $105.05(8)$ & $\mathrm{Si}(1)-\mathrm{S}(1)-\mathrm{Ni}(1)$ & $113.90(3)$ \\
\hline $\mathrm{Si}(2)-\mathrm{S}(2)-\mathrm{Ni}(1)$ & $117.40(9)$ & & & & \\
\hline
\end{tabular}

Symmetry codes: $a$ : $1-\mathrm{x}, 1-\mathrm{y},-\mathrm{z} ; b$ : $1-\mathrm{x},-\mathrm{y},-\mathrm{z} ; c:-\mathrm{x},-1,-\mathrm{y},-\mathrm{z} ; d: 1+\mathrm{x}, 1+\mathrm{y}, \mathrm{z}$

Table 3 Parameters of the hydrogen bonds in the complexes (1)-(3)

\begin{tabular}{|c|c|c|c|c|c|}
\hline Compound & Bond & $\mathrm{D}-\mathrm{H}[\AA]$ & $\mathrm{H} \cdots \mathrm{A}[\AA]$ & $\mathrm{D} \cdots \mathrm{A}[\AA]$ & $\angle \mathrm{DHA}\left[{ }^{\circ}\right]$ \\
\hline \multirow[t]{5}{*}{ (1) } & N1-H1A-O1 & $0.80(9)$ & $2.35(9)$ & $2.961(8)$ & $134(8)$ \\
\hline & N1-H1B-O4 & $0.82(9)$ & $2.28(9)$ & $3.091(8)$ & $169(8)$ \\
\hline & $\mathrm{N} 2-\mathrm{H} 2 \mathrm{~B}-\mathrm{S} 1^{a}$ & $0.84(9)$ & $2.64(9)$ & $3.469(7)$ & $172(7)$ \\
\hline & N3-H3A-S1 $1^{a}$ & $0.85(9)$ & $2.87(9)$ & $3.687(7)$ & $160(7)$ \\
\hline & N4-H4B-O1 & $0.83(8)$ & $2.56(8)$ & $3.260(8)$ & $142(7)$ \\
\hline (2) & N1-H1-O3 & $0.82(7)$ & $2.13(7)$ & 2.901(7) & $157(7)$ \\
\hline \multirow[t]{2}{*}{ (3) } & N1-H1B-O2 & $0.85(2)$ & $2.17(2)$ & 2.991(2) & $164(2)$ \\
\hline & $\mathrm{N} 2-\mathrm{H} 2 \mathrm{E}-\mathrm{O} 2^{b}$ & $0.86(2)$ & $2.32(3)$ & $3.146(2)$ & $159.3(19)$ \\
\hline
\end{tabular}

Symmetry codes: $a-\mathrm{x}+1,-\mathrm{y}+1,-\mathrm{z}) ; b \mathrm{x}-1,-\mathrm{y},-\mathrm{z}$ 
Table 4. The spin Hamiltonian parameters of some pseudo-octahedral $\mathrm{Ni}^{2+}$ complexes.

\begin{tabular}{|c|c|c|c|c|c|c|}
\hline Complex & $g_{\mathrm{x}}, g_{\mathrm{y}}, g_{\mathrm{z}}$ & $D, \mathrm{~cm}^{-1}$ & $E, \mathrm{~cm}^{-1}$ & Chromophore & $\begin{array}{c}E\left({ }^{3} \mathrm{~B}_{2 \mathrm{~g}},{ }^{3} \mathrm{~B}_{3 \mathrm{~g}}\right), \\
E\left({ }^{3} \mathrm{~B}_{1 \mathrm{~g}}\right)^{\mathrm{a}}\end{array}$ & $k_{\mathrm{x}, \mathrm{y}}^{2}, k_{\mathrm{z}}^{2}$ \\
\hline (1) & $2.191,2.202,2.143$ & 7.596 & 0.576 & $\mathrm{NiN}_{4} \mathrm{~S}_{2}$, trans & 11600,12300 & $0.89,0.68^{b}$ \\
\hline$\left\{\mathrm{Ni}(\mathrm{L}-\mathrm{tyr})_{2}\left(\mu-4,4^{\prime}-\mathrm{bpy}\right) \bullet 4 \mathrm{H}_{2} \mathrm{O}\right\}_{\mathrm{n}}{ }^{[53]}$ & $2.162,2.157,2.190$ & -5.745 & -0.428 & $\mathrm{NiN}_{2} \mathrm{~N}_{2}{ }^{\prime} \mathrm{O}_{2}$, trans & 10500,11650 & $0.66,0.87^{b}$ \\
\hline $\mathrm{Ni}(\mathrm{Im})_{2}(\mathrm{~L}-\mathrm{tyr})_{2} \bullet 4 \mathrm{H}_{2} \mathrm{O}{ }^{[17]}$ & $2.170,2.166,2.193$ & -3.010 & -0.407 & $\mathrm{NiN}_{2} \mathrm{~N}_{2}{ }^{\prime} \mathrm{O}_{2}$, cis & 10400,11800 & $0.68,0.89^{b}$ \\
\hline $\mathrm{Ni}(\mathrm{L}-\mathrm{tyr})_{2}\left(2,2^{\prime}-\mathrm{bpy}\right) \cdot 1.5 \mathrm{H}_{2} \mathrm{O}$ & $2.138,2.156,2.188$ & -3.262 & -0.109 & $\mathrm{NiN}_{2} \mathrm{~N}_{2}{ }^{\prime} \mathrm{O}_{2}$, cis & $10650,9460,11210$ & $0.58,0.57,0.82^{\mathrm{c}}$ \\
\hline$\left[\mathrm{Ni}-\left(\mathrm{HIM}_{2}-\mathrm{py}\right)_{2} \mathrm{NO}_{3}\right] \mathrm{NO}_{3}{ }^{[55]}$ & $2.17,2.17,2.17$ & -10.0 & 0.3 & $\mathrm{NiN}_{2} \mathrm{~N}_{2}{ }^{\prime} \mathrm{O}_{2}$, cis & - & - \\
\hline$[\mathrm{Ni}(\mathbf{L} 1)]\left(\mathrm{PF}_{6}\right)_{2}{ }^{[56]}$ & $2.17,2.17,2.20$ & 4.40 & 0.75 & $\mathrm{NiN}_{3} \mathrm{O}_{3}$ & - & - \\
\hline$[\mathrm{Ni}(\mathbf{L} 2)]\left(\mathrm{PF}_{6}\right)_{2}{ }^{[56]}$ & $2.17,2.16,2.20$ & -4.83 & -0.82 & $\mathrm{NiN}_{3} \mathrm{O}_{3}$ & - & - \\
\hline $\mathrm{Ni}(\mathrm{CMA})_{2}(\mathrm{Im})_{2} \cdot(\mathrm{MeOH})_{2}{ }^{[16]}$ & $2.29,2.18,2.13$ & 5.77 & 1.64 & $\mathrm{NiN}_{2} \mathrm{O}_{2} \mathrm{O}_{2}{ }^{\prime}$, trans & 8220,10770 & $0.74,0.54$ \\
\hline
\end{tabular}

${ }^{a}$ The average of the ${ }^{3} \mathrm{~B}_{2 \mathrm{~g}}$, and ${ }^{3} \mathrm{~B}_{3 \mathrm{~g}}$ energies is given except they are listed separately for $\mathrm{Ni}(\mathrm{L}-\mathrm{tyr})_{2}\left(2,2^{\prime}-\right.$ bpy) $1.5 \mathrm{H}_{2} \mathrm{O}$. ${ }^{\mathrm{b}}$ Average of $\mathrm{g}_{\mathrm{x}}$ and $\mathrm{g}_{\mathrm{y}}$ was used in calculation of $\mathrm{k}_{\mathrm{x}, \mathrm{y}}^{2}{ }^{[19]}{ }^{\mathrm{c}}$ Values of $k_{\mathrm{x}}^{2}, k_{\mathrm{y}}^{2}$ and $k_{\mathrm{z}}^{2}$ are given corresponding to $g_{\mathrm{x}}, g_{\mathrm{y}}$, and $g_{\mathrm{z}}$.

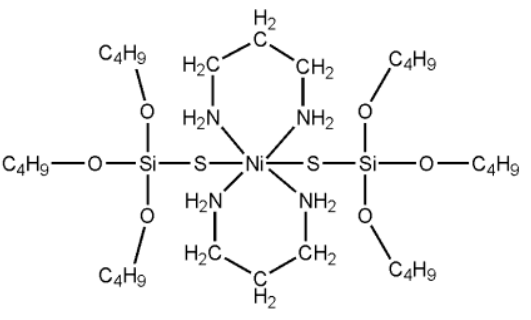

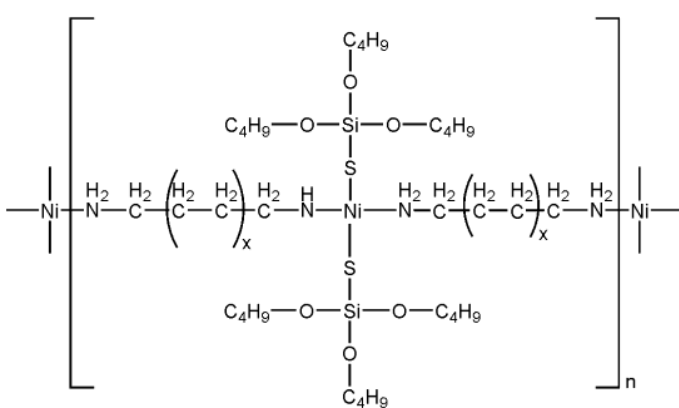

$2(x=2)$

$4(x=1)$

Scheme 1. Obtained complexes (1) -(3).

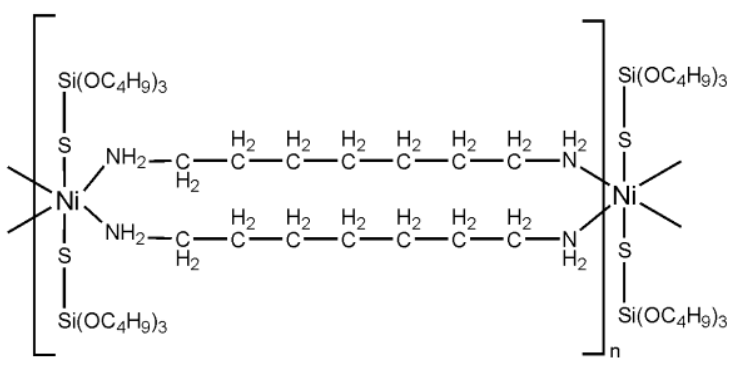

3 


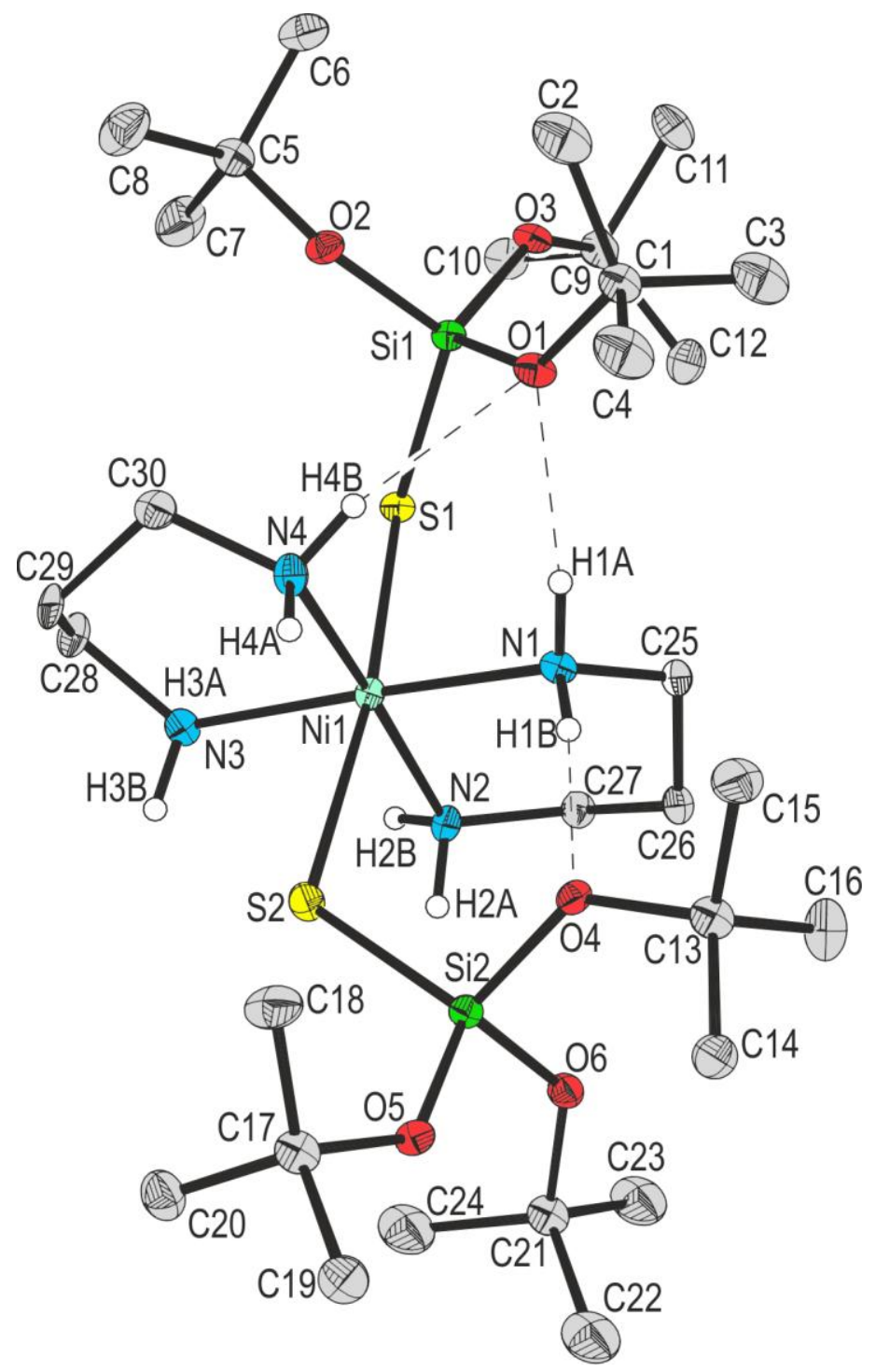

Fig 1. Molecular structure of $\left[\mathrm{Ni}\left\{\left(\mathrm{SSi}(\mathrm{O} t \mathrm{Bu})_{3}\right\}_{2}\left(\mu-\mathrm{C}_{3} \mathrm{H}_{10} \mathrm{~N}_{2}\right)_{2}\right](\mathbf{1})\right.$ with atom labeling scheme and hydrogen bond interactions (shown as dashed lines) (hydrogen atoms from $\mathrm{C}-\mathrm{H}$ bonds omitted for clarity). Thermal ellipsoids are drawn at 30\% probability. 


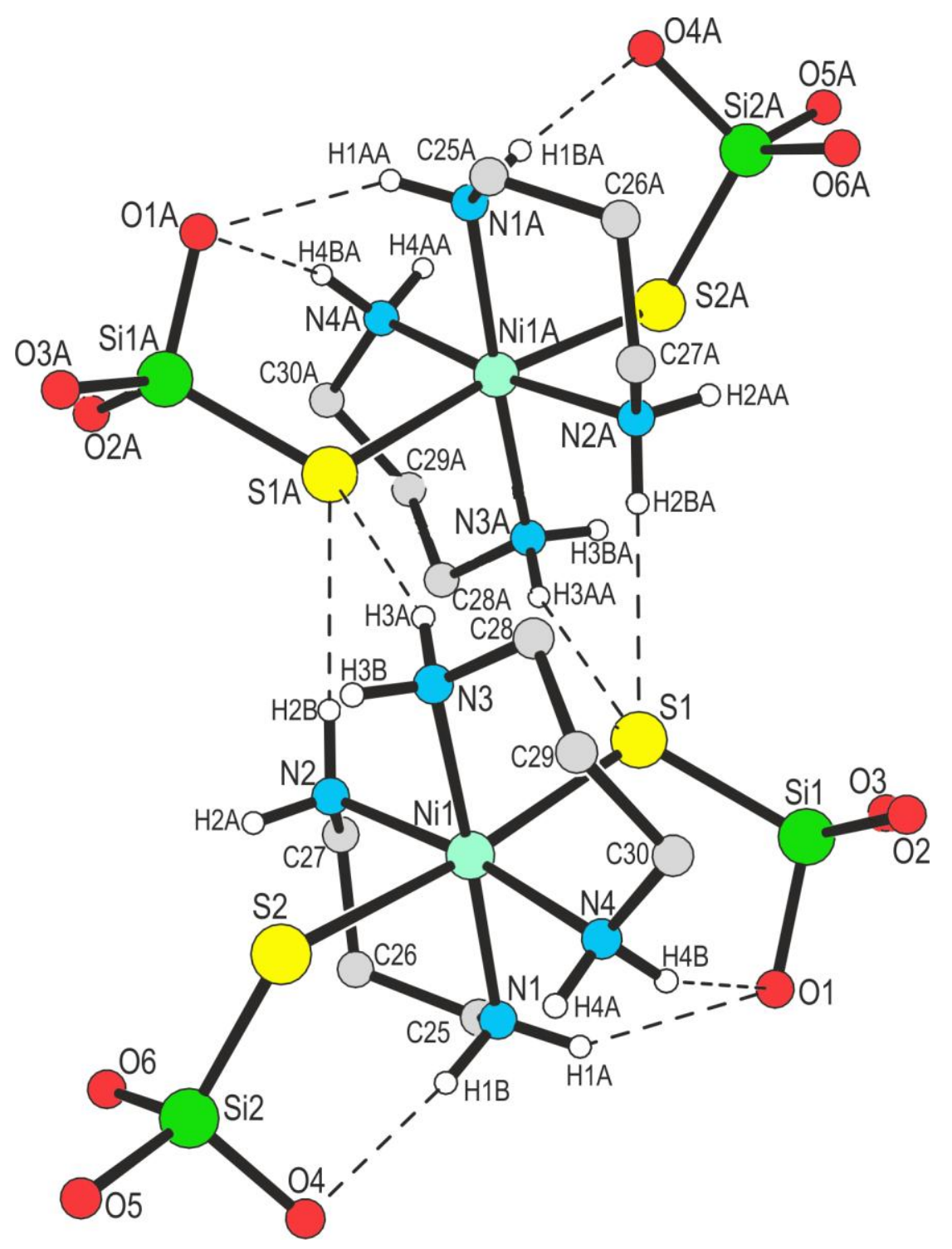

Fig. 2. Two molecules of $\left[\mathrm{Ni}\left\{\left(\mathrm{SSi}(\mathrm{O} t \mathrm{Bu})_{3}\right\}_{2}\left(\mu-\mathrm{C}_{3} \mathrm{H}_{10} \mathrm{~N}_{2}\right)_{2}\right]\right.$ (1) with atom labeling and hydrogen bonds scheme (shown as dashed lines). All $t$ Bu groups and hydrogen atoms from $\mathrm{C}-\mathrm{H}$ bonds omitted for clarity. Thermal ellipsoids are drawn at $30 \%$ probability 


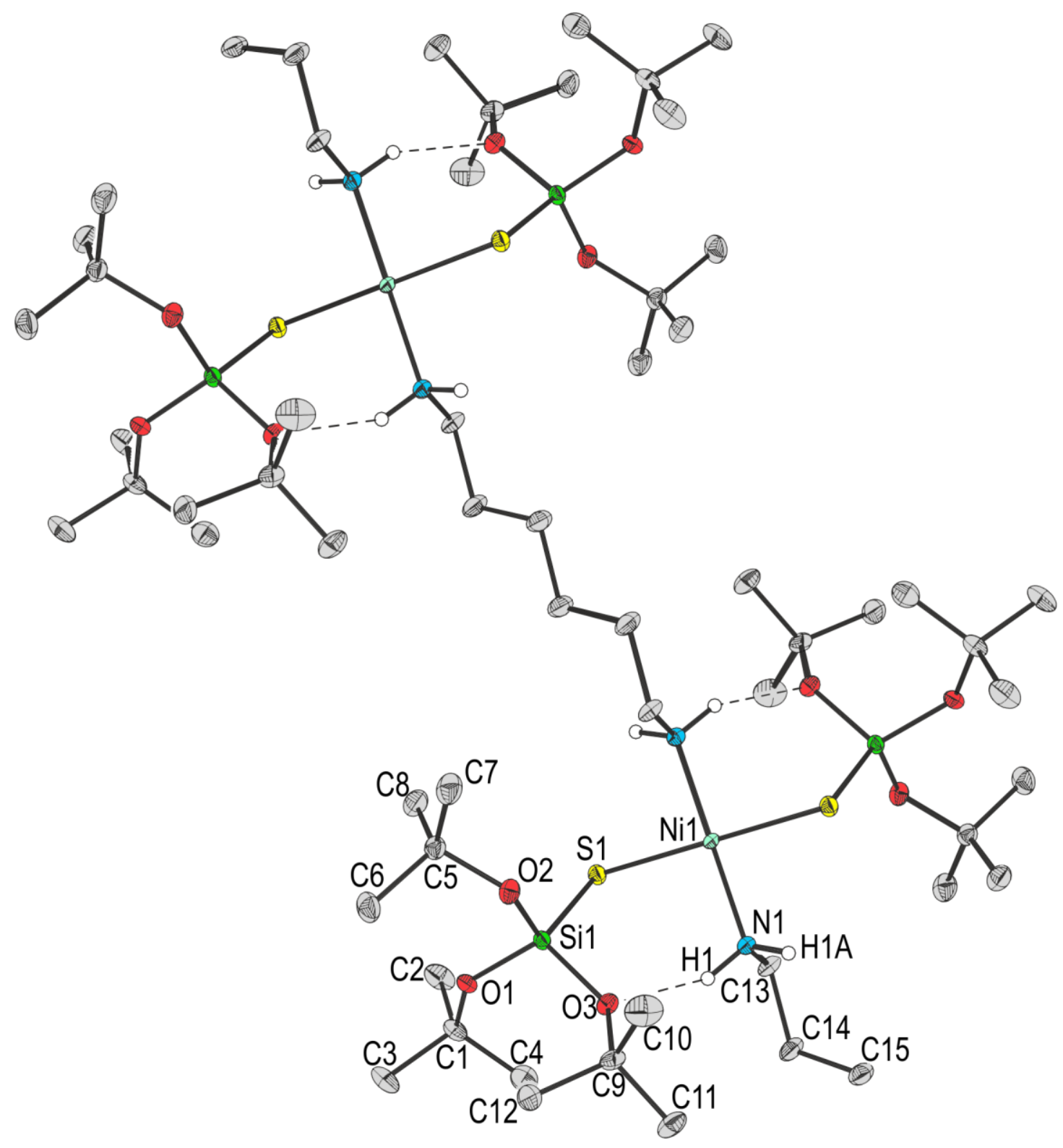

Fig 3. Molecular structure of $\left[\mathrm{Ni}\left\{\left(\mathrm{SSi}(\mathrm{O} t \mathrm{Bu})_{3}\right\}_{2}\left(\mu-\mathrm{C}_{6} \mathrm{H}_{16} \mathrm{~N}_{2}\right)_{2}\right]_{n}(2)\right.$ with atom labeling scheme and hydrogen bond interactions (shown as dashed lines) (hydrogen atoms from $\mathrm{C}-\mathrm{H}$ bonds omitted for clarity). Thermal ellipsoids are drawn at $30 \%$ probability. 


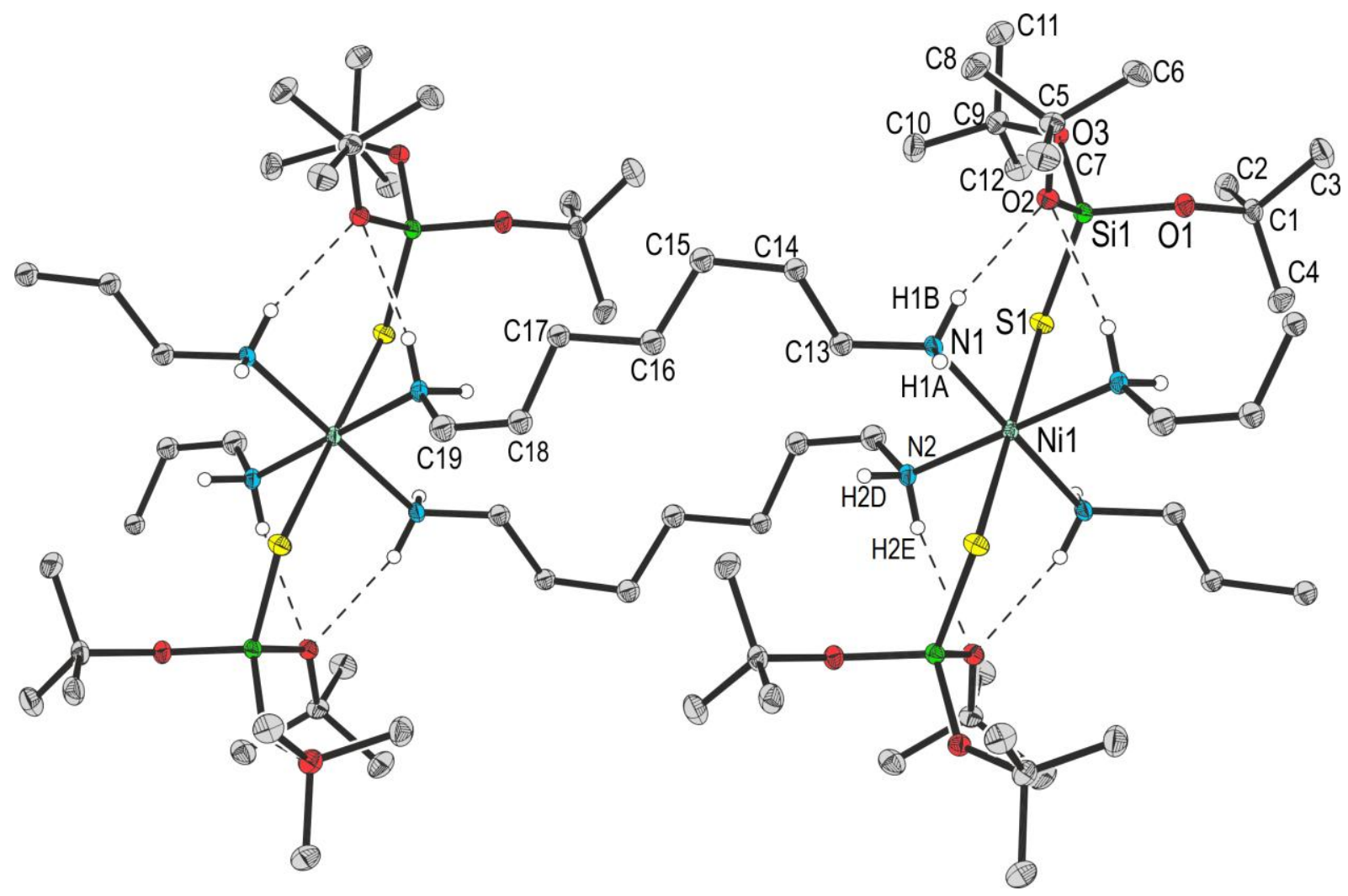

Fig 4. Molecular structure of $\left[\mathrm{Ni}\left\{\left(\mathrm{SSi}(\mathrm{O} t \mathrm{Bu})_{3}\right\}_{2}\left(\mu-\mathrm{C}_{7} \mathrm{H}_{18} \mathrm{~N}_{2}\right)_{4}\right]_{n}\right.$ (3) with atom labeling scheme and hydrogen bond interactions (shown as dashed lines) (hydrogen atoms from $\mathrm{C}-\mathrm{H}$ bonds omitted for clarity). Thermal ellipsoids are drawn at $30 \%$ probability. 


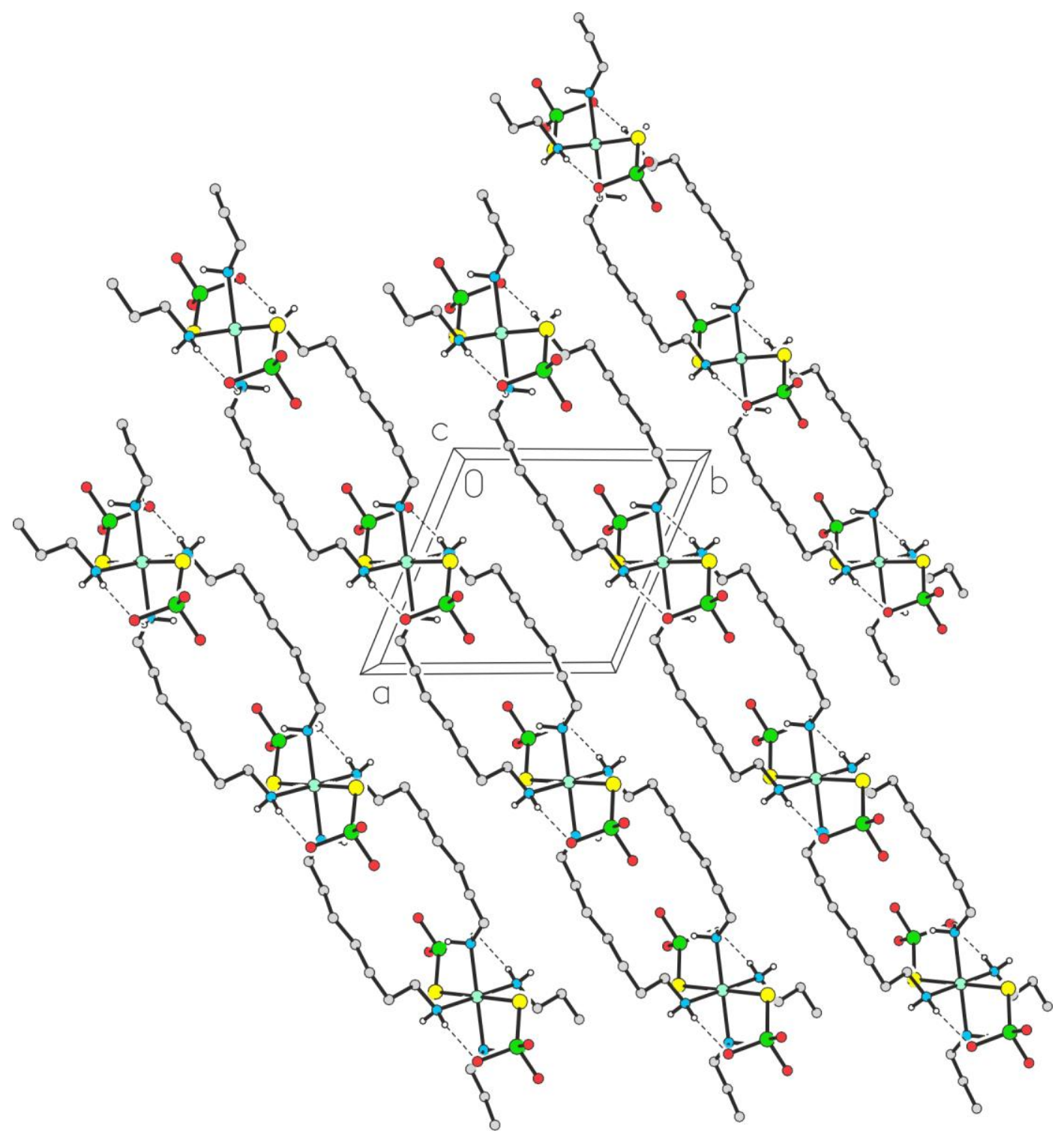

Fig. 5. Crystal packing of (3) along $c$ axis. $\mathrm{H}$ atoms and $t \mathrm{Bu}$ groups omitted for clarity. 


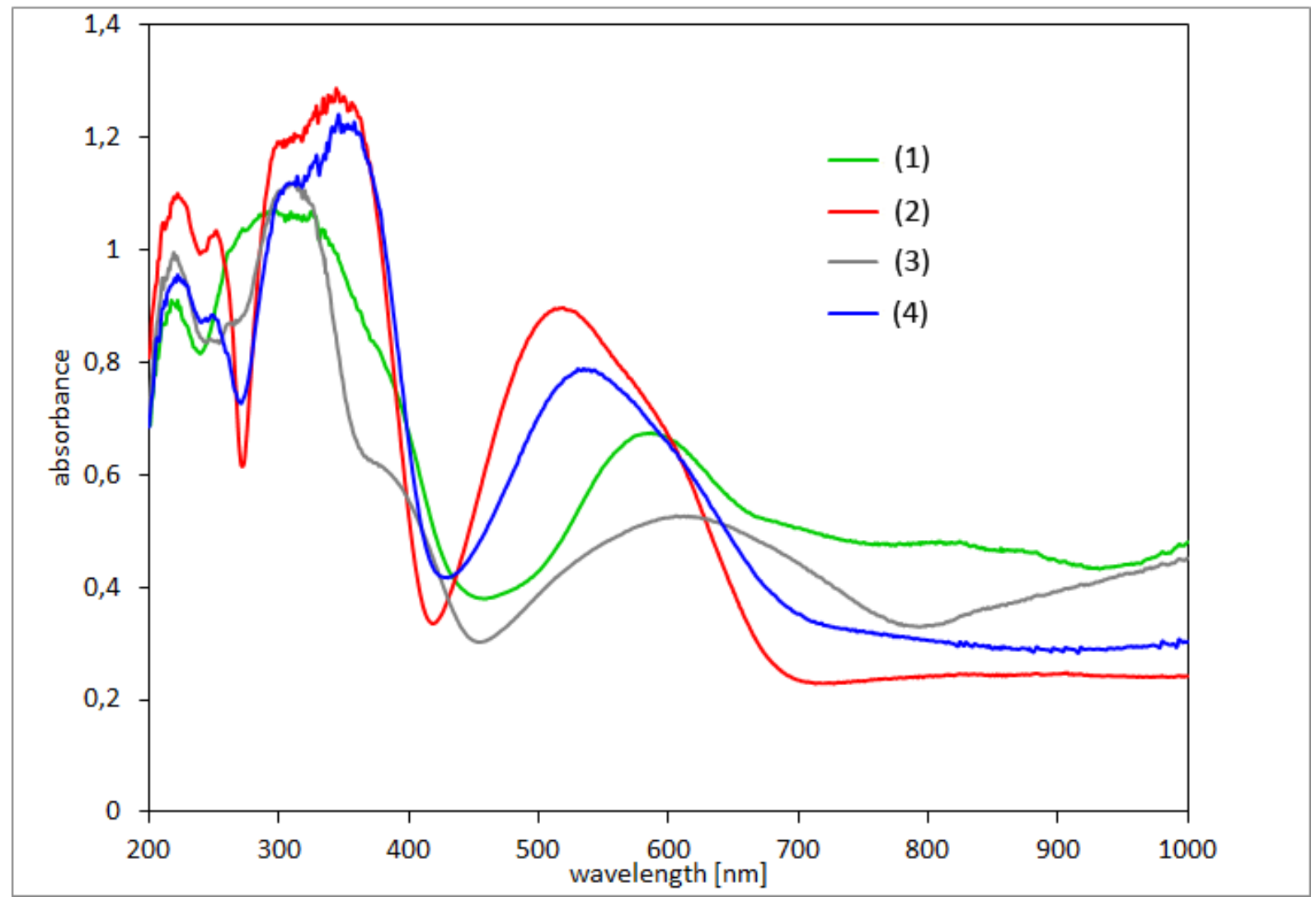

Fig. 6. Solid state electronic spectra of complexes (1)-(3).

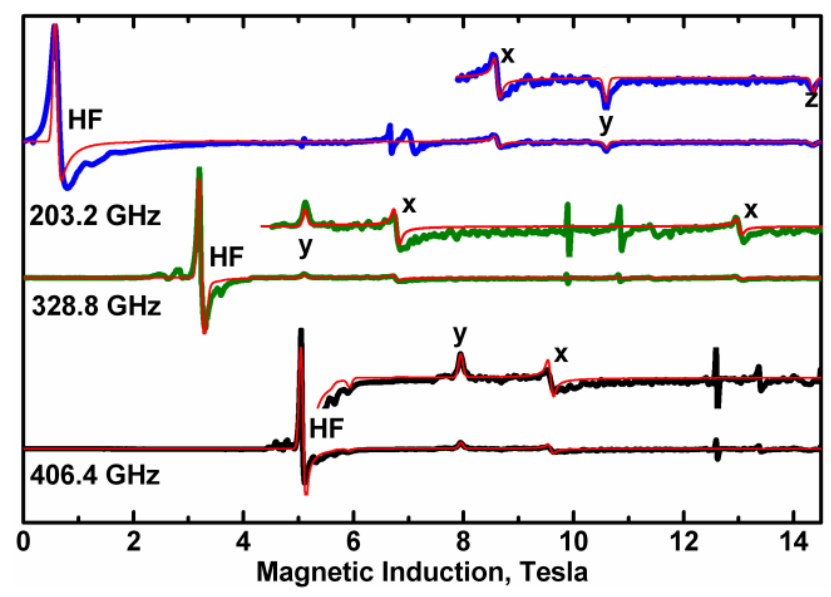

Fig 7. High-Field EPR spectra of (1) recorded at $30 \mathrm{~K}$ with the microwave frequencies as shown. $\mathrm{X}, \mathrm{Y}$ and $\mathrm{Z}$ indicate the molecular orientations for the respective resonances. $\mathrm{HF}$ is the forbidden "half-field" transition, $\Delta \mathrm{M}_{\mathrm{S}}=2$. The red traces were simulated with $g_{\mathrm{x}}=2.191, g_{\mathrm{y}}=2.202, g_{\mathrm{z}}=2.143, D=7.596 \mathrm{~cm}^{-1}, E=0.576 \mathrm{~cm}^{-1}$. 


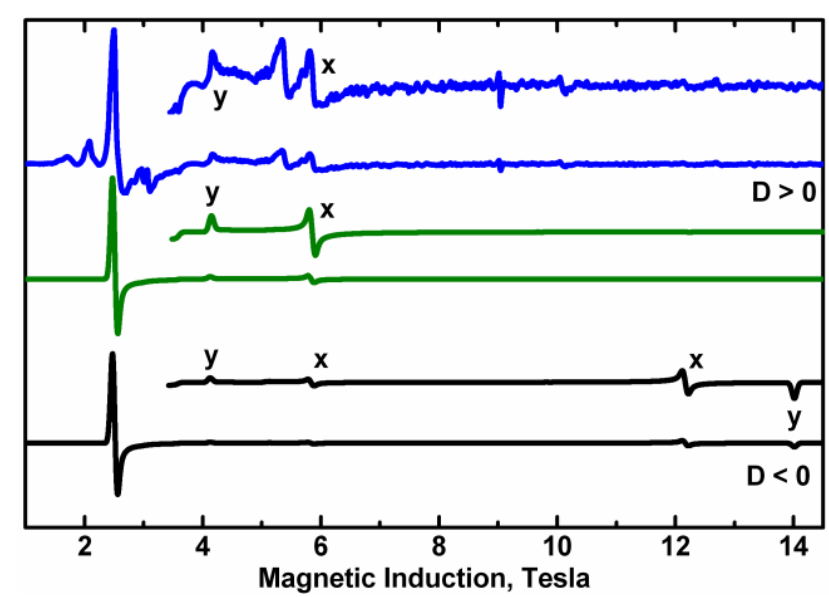

Fig 8. HF EPR spectrum of (1) at $5 \mathrm{~K}$ with the microwave frequency $304.8 \mathrm{GHz}$. Blue: experimental. Green: calculated with $D=7.596 \mathrm{~cm}^{-1}, E=0.576 \mathrm{~cm}^{-1}$; black: calculated with $D=-7.596 \mathrm{~cm}^{-1}, E=-0.576 \mathrm{~cm}^{-1}$.

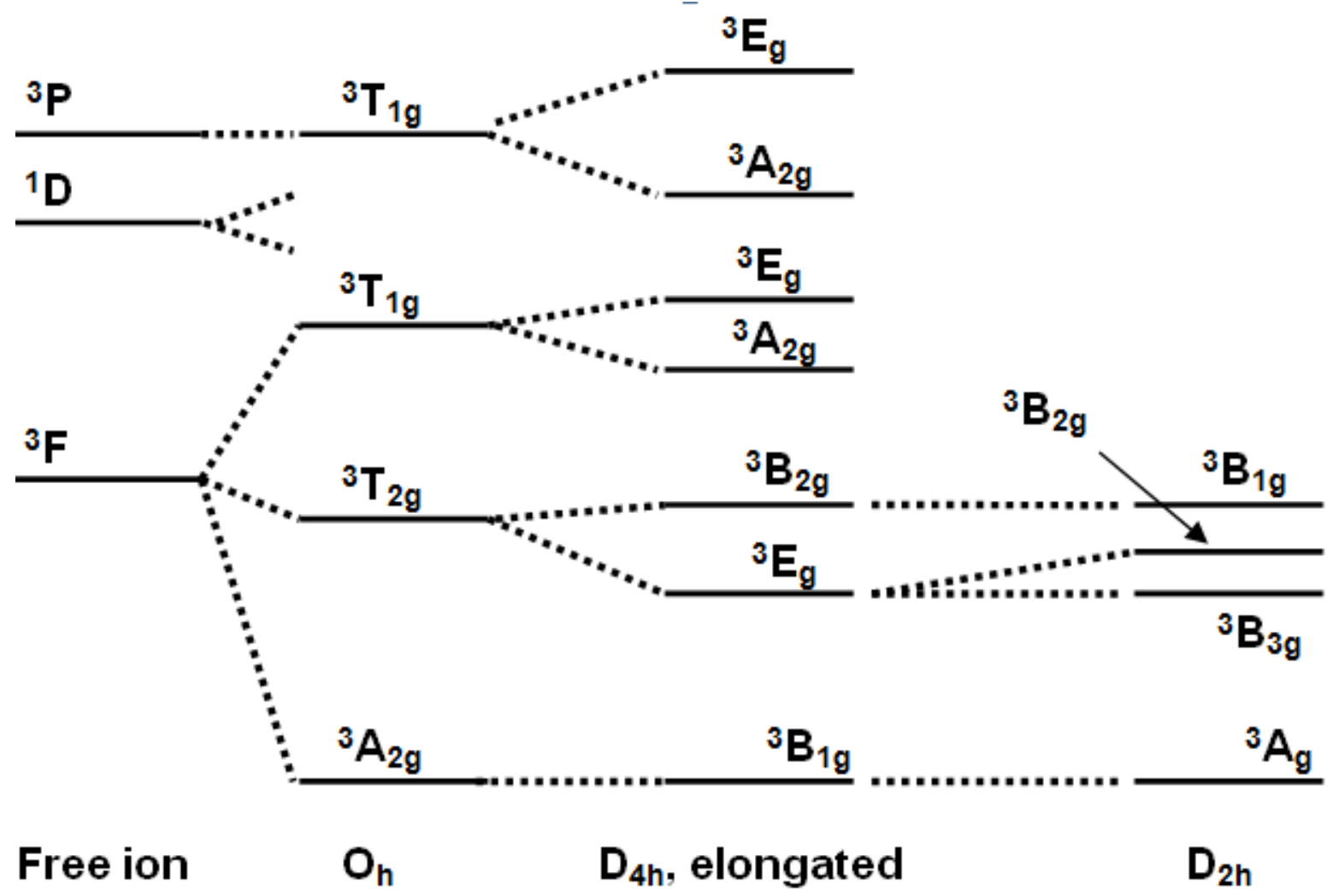

Fig 9. Energy level diagram for a d ${ }^{8}$ ion in octahedral $\left(\mathrm{O}_{\mathrm{h}}\right)$, tetragonal $\left(\mathrm{D}_{4 \mathrm{~h}}\right)$ environment and for the lowest two Oh states ${ }^{3} \mathrm{~T}_{2 \mathrm{~g}}$ and ${ }^{3} \mathrm{~A}_{2 \mathrm{~g}}$ in rombic $\left(\mathrm{D}_{2 \mathrm{~h}}\right)$ surroundings. 

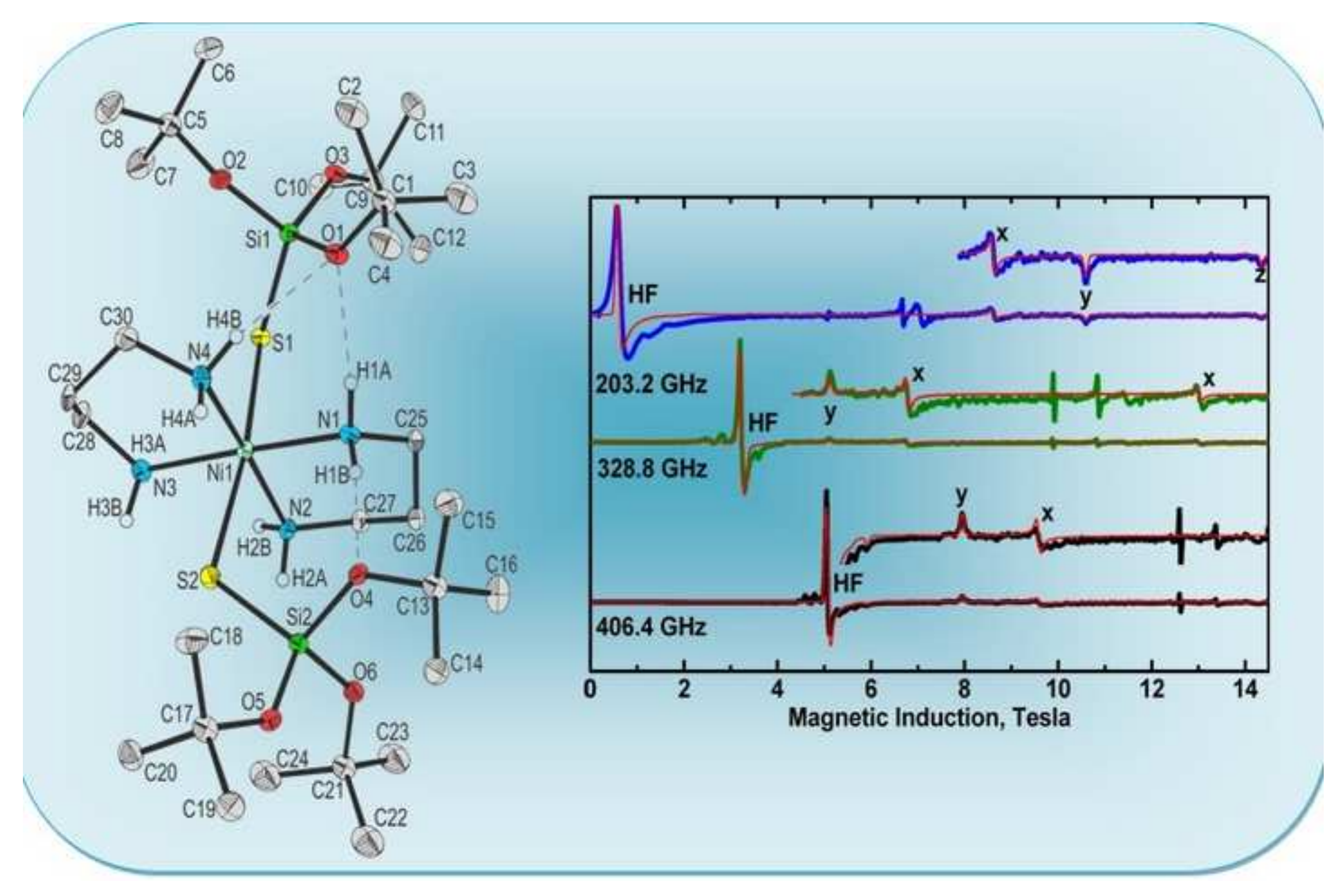
Five new nickel silanethiolates with diamines have been obtained. X-ray crystallography and spectroscopic methods FT-IR, UV-Vis and HF EPR followed. Complexes (2) and (3) are 1D coordination polymers showing different topology. Thermal stability of (2)-(4) complexes studied with TG-DTG 